\title{
UWAGI NA TEMAT OBRZĄDKU POGRZEBOWEGO GRUPY OLSZTYŃSKIEJ NA PRZYKŁADZIE CMENTARZYSKA W KOSEWIE, POW. MRĄGOWSKI (DAWN. KOSSEWEN, KREIS SENSBURG)
}

SŁowa KLuczowe: grupa olsztyńska; Bałtowie Zachodni; okres wędrówek ludów; wczesne średniowiecze,;obrządek pogrzebowy

Keywords: Olsztyn Group; West Balts; Migration Period; Early Middle Ages; funeral rite

Cmentarzysko w Kosewie (dawne Kossewen, Kr. Sensburg, od 1938 Rechenberg) jest jedną $\mathrm{z}$ największych znanych nekropoli datowanych na okres wpływów rzymskich i okres wędrówek ludów na Pojezierzu Mazurskim (mapa I). Stanowisko to, położone w przesmyku między jeziorem Juksty i Jeziorem Probarskim (ryc. 1), odkryto przypadkowo podczas prac przy budowie drogi Mragowo - Mikołajki w 1887 roku. Duża liczba odkrytych przedmiotów z brązu i żelaza skłaniała do podjęcia badań ratowniczych, które przeprowadził Max Weigel z berlińskiego Museum für Völkerkunde (Weigel 1891). Podczas wykopalisk M. Weigla odkryto 29 grobów ciałopalnych, głównie popielnicowych oraz znaczną ilość zabytków luźnych. Do najbardziej okazałych zespołów należy inwentarz grobu 14., w którym znajdował się między innymi importowany szklany pucharek typu Snartemo, grzebień, ostrogi nitowe oraz srebrne elementy garnituru pasa (Weigel 1891: 24-25; Ebert 1926: 73; Nowakowski 1998: 98; 2001: 62-63). Wyposażenie tego grobu jest obecnie uważane za jeden z najwcześniejszych zespołów grupy olsztyńskiej (Nowakowski 2000c: 16). W latach 1907-1908 roku badania na cmentarzysku kontynuował królewiecki badacz Feliks Ernst Peiser, członek oraz późniejszy prezes Altertümsgesellschaft 
Prussia (ryc. 2). W bliskiej okolicy, nad Jeziorem Probarskim, znajdowały się jeszcze dwa inne cmentarzyska datowane na okres wpływów rzymskich i okres wędrówek ludów, określone jako Kosewo II i Kosewo III. (PM-A 1848).

Pomimo dużej liczby obiektów ${ }^{1}$ na cmentarzysku w Kosewie $(29$ z badań M. Weigla i co najmniej $811 \mathrm{~F}$. Peisera ${ }^{2}$ ), stanowisko to znane jest jedynie z publikacji pojedynczych zabytków lub zespołów. Materiał zabytkowy, pozyskany z badań w latach 1907-1908, trafił do Prussia Museum w Królewcu, gdzie dopełnił losu wielu innych zabytków przechowywanych w tej placówce. Pod koniec drugiej wojny światowej większość znalezisk zaginęła lub została rozproszona (por. Nowakowski 1995: 14-15). Liczne kwerendy muzealne i archiwalne pozwoliły jednak w dużym stopniu odtworzyć obraz tej nekropoli oraz zarejestrować wiele cech obrządku pogrzebowego grupy olsztyńskiej w późnym okresie wędrówek ludów, jak i kultury bogaczewskiej, której ludność użytkowała nekropolę w okresie wpływów rzymskich.

Za jedno z najważniejszych źródeł do poznania stanowiska należy uznać materiały zgromadzone w tzw. Ortsakten, czyli teczkach zawierających materiały archiwalne, które dotyczyły badań w obrębie danej miejscowości na terenie dawnych Prus Wschodnich. Materiały te znajdują się obecnie w PrussiaMuseum Archiv w Museum für Vor- und Frühgeschichte w Berlinie. Ortsakte Kossewen zawiera szczególnie ważne źródło informacji, jakim jest odpis dziennika polowego F. E. Peisera, autora badań na cmentarzyskach w Kosewie. We wspomnianej teczce znajduje się rękopiśmienna kopia sporządzona przez pracownika muzeum Thiessena w 1924 roku w Królewcu, najprawdopodobniej na polecenie M. Eberta, ówczesnego dyrektora Prussia Museum (Nowakowski 2004a: 362) oraz maszynowa kopia nieznanego autora z 1942 roku3 $^{3}$. Oba odpisy nie są kompletne, lecz w wielu miejscach się dopełniają umożliwiając sporządzenie katalogu obiektów na cmentarzyskach.

${ }^{1}$ Celowo użyto określenia obiekty, jako że w swoim sprawozdaniu F. E. Peiser nadawał kolejne numery również zabytkom luźnym oraz obiektom, w których, jak podkreślał, nie było kości (PM-A 1848/1).

${ }^{2}$ W. Nowakowski podaje 854 jako liczbę grobów z badań F. E. Peisera. Liczba ta przytaczana jest zapewne za Kartoteką Kurta Voigtmanna, w której znajduje się karta z opisem grobu nr 854. Należy jednak podkreślić, iż numer ten został opatrzony przez autora kartoteki znakiem zapytania. Świadczy to, że K. Voigtmann, skądinąd bardzo skrupulatny, nie był pewien, czy dany grób rzeczywiście nosił nr 854. W sprawozdaniu F. Peisera z badań inwentarz grobów kończy się na liczbie 811 (PM-A 1848/1; PM-A 1848/2). Brak jest danych z innych źródeł, aby jednoznacznie stwierdzić, iż liczba grobów odkrytych na cmentarzysku w Kosewie przekroczyła tę liczbę.

${ }^{3}$ Informacja pochodzi od p. Horsta Wiedera, pracownika Prussia-Museum Archiv w Museum für Vor- und Frühgeschichte w Berlinie. 
Niezwykle istotnym źródłem jest tzw. Voigtmanns Kartei, czyli kartoteka Kurta Voigtmanna, również przechowywana w Museum für Vor- und Frühgeschichte w Berlinie. Znajdują się w niej karty zawierające szczegółowe informacje dotyczące materiału zabytkowego i lokalizacji obiektów ${ }^{4}$. Karty te zaopatrzone są często w precyzyjne rysunki zabytków oraz zdjęcia. W Prussia-Museum Archiv znajduje się również tzw. Foto-Archiv, które dostarczyło wielu zdjęć zabytków z Kosewa, szczególnie tak słabo znanych, jak naczynia ceramiczne.

Do nie mniej ważnych źródeł należy także spuścizna łotewskiego badacza Feliksa Jakobsona, przechowywana w Latvijas Nacionālais Vēstures Muzejs w Rydze, w której znajdują się zilustrowane i opisane liczne zespoły grobowe, choć jakość rysunków jest zdecydowanie mniejsza niż w przypadku wspomnianej wcześniej Voigtmanns Kartei. Liczne informacje na temat poszczególnych zabytków pochodzą również z kartoteki estońskiej, archeolog Marthy Schmiedehelm, przechowywanej w Ajaloo Instituut w Tallinie. Kartoteka ta zawiera wiele cennych informacji na temat zespołów z okresu wpływów rzymskich, nieuwzględnionych przez K. Voigtmanna i F. Jakobsona, którzy zajmowali się głównie okresem wędrówek ludów. Należy jednak podkreślić, iż zawarte w niej rysunki są najczęściej schematyczne i niezbyt dobrej jakości. Wiele informacji dostarczyła także spuścizna Nilsa Åberga, przechowywana w Riksantikvarieämbetet, ATA w Sztokholmie, zawierająca rysunki przede wszystkim zapinek. Wydaje się. że materiały te pochodzą z okresu zbierania przez N. Åberga danych do jego książki Ostpreussen in der Völkerwanderungszeit, wydanej w 1919 roku w Uppsali. Cennymi źródłami, choć zawierającymi o wiele mniej informacji, okazała się również spuścizna naukowa Carla Engla, przechowywana w Johann Gotfried Herder Instytut w Marburgu, spuścizna naukowa Rudolfa Grenza, przechowywana w Archäologisches Landesmuseum Schleswig oraz spuścizna Carla Axla Moberga, obecnie w Göteborg Uniwersitetsbibliotek. Cennych danych dostarczają również opublikowane archiwalia fotograficzne zebrane w kolekcji dydaktycznej stworzonej przez A. M. Tallgrena dla Uniwersytetu w Tartu, przechowywanej w Ajaloo Instituut w Tallinie (por. Juga, Ots, Szymański 2003).

Analizując materiały z cmentarzysk w Kosewie nie należy zapominać o dość nielicznych publikacjach ilustrujących materiał zabytkowy. Do najwcześniejszych i najistotniejszych źródeł należy sprawozdanie z badań M. Weigla z badań w 1891 roku. Publikacja ta zawiera opis lokalizacji cmentarzyska Kosewo I

\footnotetext{
${ }^{4}$ Wydaje się, iż K. Voigtmann mógł korzystać z oryginalnego dziennika F. E. Peisera, lecz nie można tego jednoznacznie stwierdzić.
} 
wraz z mapą, a także katalog grobów wzbogacony o materiał ilustracyjny przedstawiający wybrane zabytki. Artykuł ten pozytywnie odbija się na tle innych publikacji archeologicznych z tego okresu ${ }^{5}$.

Najliczniejszy zbiór zabytków z cmentarzyska I w Kosewie opublikował W. Nowakowski (1998a). Publikacja ta zawiera rysunki i opisy zabytków pochodzących z badań M. Weigla oraz przedmiotów odkrytych przypadkowo w 1887 roku podczas budowy drogi. Badacz ten opublikował również zbiór importów rzymskich ze wspomnianego cmentarzyska (Nowakowski 2001). Istotną publikacja, opartą na wynikach kwerend muzealnych i archiwalnych, zawierającą niepublikowany wcześniej materiał zabytkowy oraz historię badań na nekropolach w Kosewie, jest artykuł poświęcony grobowi nr 600 (Nowakowski 2005). Wybrane materiały z cmentarzysk w Kosewie były publikowane między innymi przez N. Åberga (1919), W. Gaertego (1926), K. Voigtmanna (1941) czy H. Kühna (1956). Najnowszym źródłem uwzględniającym materiały z Kosewa jest opracowanie znalezisk fibul płytkowych z terenów zachodniobałtyjskich autorstwa V. Hilberga (2009).

Liczba publikacji zawierających informacje o pojedynczych zabytkach jest o wiele wyższa, lecz nawet ich pełne zestawienie niewiele wnosi do stanu źródeł, gdyż zwykle dotyczą one najbardziej znanych, szczególnie efektownych zabytków, których ilustracje były wielokrotnie przedrukowywane (por. Rudnicki 2010).

W badaniach nad cmentarzyskami w Kosewie ważną rolę odegrały również kwerendy muzealne. Wiele zabytków ze zniszczonego Prussia Museum w Królewcu uległo bezpowrotnemu zniszczeniu w czasie ostatniej wojny światowej. Część eksponatów została jednak ewakuowana w 1943 i 1944 roku z zagrożonego miasta i przewieziona w głąb Rzeszy. Niektóre z tych zabytków znajdują się obecnie w Prussia Sammlung w Museum für Vor- und Frühgeschichte $\mathrm{w}$ Berlinie, gdzie stanowią obecnie przedmiot konserwacji i katalogowania (Reich, Menghin 2008: 71-85). W zbiorze tym natrafiono na dwa paciorki szklane pochodzące $\mathrm{z}$ cmentarzyska Kosewo I, grób 655. Pewna partia zabytków, ewakuowana z Królewca, zdeponowana została na terenie dawnego szpitala psychiatrycznego w Karolewie, gdzie w 1946 roku została zabezpieczona przez Z. Lichariewą i E. Gałdziewicza, a następnie zdeponowana przez J. Antoniewicza w Muzeum Mazurskim w Olsztynie (Bitner-Wróblewska 2008: 49-51). Obecnie w Muzeum Warmii i Mazur w Olsztynie (dawne Muzeum

\footnotetext{
${ }^{5}$ Odmienny pogląd reprezentuje W. Nowakowski $(2005,362)$.
} 
Mazurskie) znajdują się trzy naczynia cmentarzyska Kosewo I i jedno naczynie z cmentarzyska Kosewo III.

Część zabytków, których nie zdołano ewakuować przed oblężeniem Królewca w 1944 roku, zmagazynowano w forcie III w dawnej dzielnicy Quednau, gdzie pozostały do roku 1999. Wiele z nich zostało następnie zrabowanych i rozproszonych w prywatnych kolekcjach. Znaczna liczba trafiła jednak do Muzeum Historyczno-Artystycznego w Kaliningradzie, reprezentując różny stan zachowania (Valujev 1995: 49-111; 2008: 98-109). W placówce zidentyfikowano kilka zabytków z Kosewa, wśród nich niektóre, szczególnie efektowne, takie jak importowana, gepidzka Adlerschnalle i srebrna zapinka z grobu 368 z cmentarzyska Kosewo I, czy brązowa zapinka płytkowa z grobu 172 z cmentarzyska Kosewo III. Przedmioty te stanowią obecnie część ekspozycji.

Odmienne losy spotkały zabytki pochodzące z badań M. Weigla, które trafiły do dawnego Museum für Völkerskunde w Berlinie jeszcze w XIX w. Historia oszczędziła im burzliwych losów zabytków z dawnego Prussia Museum i znajdują się one obecnie w zbiorach Museum für Vor- und Frühgeschichte w Berlinie. Stały się one przedmiotem opracowania W. Nowakowskiego i zostały opublikowane w 1998 roku (Nowakowski 1998a). Należy przy tym podkreślić, iż wybrane przedmioty z badań M. Weigla (grób 14) są również eksponowane na wystawie w otwartym w 2009 roku gmachu Neues Museum.

Cmentarzysko Kosewo I jest to wielofazowa nekropola ${ }^{6}$, posiadająca rozpiętość użytkowania od schyłku okresu wczesnorzymskiego po koniec późnego okresu wędrówek ludów (ryc. 3). Łącznie na tym cmentarzysku odkryto co najmniej 834 obiekty, w tym co najmniej 728 grobów ciałopalnych (patrz tabela 1). Wśród obiektów o określonej chronologii dominowały groby grupy olsztyńskiej datowane na fazę E (151 obiektów), co stawia tę nekropolę w rzędzie największych cmentarzysk grupy olsztyńskiej. Nie można jednak traktować tych liczb jako pełne odzwierciedlenie sytuacji na cmentarzysku, ponieważ brak jest informacji o przynajmniej 82 obiektach, a spośród wszystkich uchwyconych obiektów ponad połowa (444 obiekty) nie posiada precyzyjnie określonej chronologii. Datować je można bardzo szeroko od wczesnego okresu wpływów rzymskich do późnego okresu wędrówek ludów7 ${ }^{7}$ Należy zatem dopuścić o wiele większą

\footnotetext{
${ }^{6} \mathrm{~W}$ świetle dostępnych źródeł za największe wielofazowe (B-E) cmentarzysko należy uznać nekropolę w Miętkich (co najmniej 856 obiektów). Za tę informację dziękuję mgr I. Szter.

${ }^{7} \mathrm{Na}$ cmentarzysku nie zarejestrowano materiałów datowanych wcześniej niż faza B, okresu wpływów rzymskich i późniejszych niż faza E, okresu wędrówek ludów.
} 
liczbę grobów grupy olsztyńskiej na omawianym cmentarzysku. Na podstawie zebranego materiału można jednak poczynić wiele obserwacji na temat obrządku pogrzebowego grupy olsztyńskiej w późnym okresie wędrówek ludów.

Nekropola Kosewo I znajduje się na niewielkim wyniesieniu w przesmyku między jeziorem Juksty i Jeziorem Probarskim. W przesmyku między Jeziorem Probarskim a jeziorem Zjadło znajduje się również odległe o około $2 \mathrm{~km}$. cmentarzysko Kosewo III. Położenie cmentarzysk grupy olsztyńskiej w przesmykach między zbiornikami wodnymi lub na wyniesieniach w bezpośrednim sąsiedztwie jezior, to cecha charakterystyczna tej jednostki kulturowej. Odległość nekropoli od zbiornika wodnego nie przekraczała zwykle 300-400 m. Ze względu na stan badań trudno jest określić odległość nekropoli od osad. Nieliczne znane przykłady, jak np. Wyszembork czy Tumiany wskazują jednak, iż cmentarzyska znajdowały się zwykle w odległości kilkuset metrów do ok. 2-3 kilometrów od osad użytkującej je ludności. Jedno cmentarzysko mogło być również użytkowane przez 2-3 osady (Szymański 2005: 160; Hilberg 2009: ryc. 2.3, 45). W przypadku Kosewa nie udało się jednakże zlokalizować osady należącej do ludności użytkującej nekropolę.

Obrządek pogrzebowy grupy olsztyńskiej nie został jak dotąd monograficznie opracowany. Grupa olsztyńska w fazie E, podobnie jak wcześniejsza kultura bogaczewska cechuje się wyłącznie ciałopalnym obrządkiem pogrzebowym (Hollack, Peiser 1904: 12; Gaerte 1929: 262; Engel 1935: 98; Jaskanis 1974: 140). Na cmentarzyskach w Kosewie, wśród form grobów można wyróżnić groby jamowe i popielnicowe. Groby jamowe poza szczątkami zmarłego zawierały również zwykle pozostałości stosu ciałopalnego. Mamy więc do czynienia z formami grobów, które w zasadzie nie różnią się od obiektów sepulkralnych z okresu wpływów rzymskich. Spotykane w niemieckojęzycznej literaturze określenia Aschenhaufen i Knochenhaufen odnoszą się kolejno do grobów jamowych zawierających pozostałości stosu pogrzebowego oraz bez szczątków stosu i są reprezentowane również na cmentarzyskach w Kosewie.

W literaturze przyjmuje się, iż w grupie olsztyńskiej dominują groby popielnicowe (Hollack, Peiser 1904: 12; Jaskanis 1974: 140). Niestety, nie można przedstawić szczegółowych zestawień statystycznych obrazujących stosunek poszczególnych form grobów dla cmentarzysk w Kosewie, jak i dla większości nekropoli grupy olsztyńskiej. Jest to spowodowane brakiem danych o datowaniu ubogo wyposażonych grobów bądź grobów pozbawionych wyposażenia, które pomijane były często w przedwojennej dokumentacji cmentarzysk. Kolejną przeszkodą jest całkowity brak danych dotyczących znacznej liczby obiektów, który wynika z rozproszenia bądź zniszczenia części dokumentacji polowej. 
Obliczeń takich nie da się stworzyć także dla faz użytkowania cmentarzysk, wiązanych z okresem wpływów rzymskich, ponieważ brak danych o chronologii grobów pozbawionych datującego inwentarza znacznie zaniża poziom wiarygodności obliczeń ${ }^{8}$. Z analogiczną sytuacją spotykamy się na cmentarzysku w Kosewie. Na omawianej nekropoli dominowały groby popielnicowe. Wśród 728 zarejestrowanych grobów, bezwzględną większość stanowiły groby popielnicowe - 611. Spośród 124 grobów datowanych na okres wpływów rzymskich, groby popielnicowe (76) stanowiły 59\%. Pomimo dużej możliwości błędu wynikającej z braku danych o chronologii większości grobów odkrytych na cmentarzysku, wydaje się, że można zaryzykować twierdzenie o przewadze obrządku popielnicowego wśród grobów kultury bogaczewskiej. Taka sytuacja znajduje analogie również na innych wielofazowych cmentarzyskach na Mazurach (Okulicz 1973: 393; Jaskanis 1974: 137; Nowakowski 2007: 124). Odmienne zjawisko zarejestrowano na cmentarzyskach w Wyszemborku (Szymański 2005: 88) czy Sterławkach Wielkich (Lenarczyk 1991), gdzie dominował obrządek bezpopielnicowy.

Dominację obrządku popielnicowego stwierdzono również w przypadku grobów datowanych na okres wędrówek ludów. Spośród 149 pewnie datowanych na fazę E grobów grupy olsztyńskiej, bezwzględną większość (140) stanowiły groby popielnicowe. Zjawisko to odpowiada sytuacji występującej na stosunkowo niedalekim, wielofazowym cmentarzysku w Muntowie (Nowakowski 2004b: 216). W Zalcu stosunek grobów popielnicowych datowanych na fazę $\mathrm{E}$ do jamowych wynosił około 10:1 (Szymański 2004: 176). Porównanie z tymi nekropolami, leżącymi stosunkowo blisko Kosewa, jest szczególnie istotne, gdyż może wskazywać na brak lokalnych różnic w zakresie obrządku pogrzebowego na terenie mikroregionu w rejonie Jeziora Probarskiego z cmentarzyskami w Wyszemborku, Zalcu, czy Muntowie ${ }^{9}$ ). Zbliżona sytuacja wystapiła również na jednofazowym (faza E) cmentarzysku Kosewo III, gdzie zarejestrowano łącznie 253 obiekty, w tym 250 grobów ciałopalnych (Rudnicki 2010a: 163164). Wśród nich bezwzględną większość stanowiły groby popielnicowe - 226 . Na tym cmentarzysku zarejestrowano tylko 24 groby bezpopielnicowe ${ }^{10}$.

${ }^{8}$ Dla stanu badań nad mazurskimi stanowiskami archeologicznymi, badanymi przed drugą wojną światową por. (Nowakowski 1995; 2000b).

${ }^{9} \mathrm{Na}$ temat określania zasięgu mikroregionu osadniczego względem centralnego cmentarzyska por. Szymański 2005: 153-155.

${ }^{10}$ Statystyki te opierają się na wynikach badań F.E. Peisera z 1908 r. W latach 2014-2015 na cmentarzysku Kosewo III przeprowadzono badania wykopaliskowe, które doprowadziły do odkrycia kolejnych obiektów sepulkralnych (Gładki, Stokłosa 2015a: 26-27) 
Analogiczną sytuację zarejestrowano także na cmentarzyskach datowanych wyłącznie na fazę E w zachodniej strefie osadnictwa grupy olsztyńskiej w Tumianach (Heydeck 1895; Jakobson 2009), Kielarach (Hollack, Bezzenberger 1900; Jakobson 2009) czy Leleszkach (Bujack 1880). Odmienna sytuacja wystapiła na cmentarzysku w Wyszemborku, gdzie zdecydowanie dominowały groby jamowe. Na 17 grobów popielnicowych przypadało tam 51 pochówków jamowych (Szymański 2004: 177). Groby bezpopielnicowe przeważały również na cmentarzysku w Pieckach ${ }^{11}$.

Wydaje się więc, iż przyjąć należy ogólną przewagę pochówków popielnicowych w grupie olsztyńskiej, dopuszczając jednak lokalne odstępstwa od tego zwyczaju. Zjawisko to było już wcześniej sygnalizowane w literaturze ${ }^{12}$ (Jaskanis 1974: 147). Ustalenia te opierają się jednak głównie na badaniach przedwojennych, których metodyka nie zawsze pozwalała uchwycić wszystkie obiekty na cmentarzysku. Należy więc oczekiwać zweryfikowania powyższych ustaleń w miarę przybywania wyników badań współczesnych.

Najnowsze badania na cmentarzysku w Burdagu ${ }^{13}$ ujawniły także, iż w wielu przypadkach popielnice nie były wypalane. Naczynia te w momencie odkrycia prezentują fatalny stan zachowania, co mogło uniemożliwić metodyczne wyeksplorowanie ich podczas dawnych, amatorskich badań. W innych przypadkach szczątki zmarłego wraz z wyposażeniem składano w nieckach wylepionych gliną. Te formy obrządku pogrzebowego, jak dotąd, nie były wzmiankowane przez badaczy.

Typowymi dla grupy olsztyńskiej są tzw. popielnice okienkowe - Fensterurnen i pochodne od nich popielnice otworowe - Lochurnen. Licznie spotyka się również naczynia z wycięciem w krawędzi wylewu - Gefäße mit Randausschnitt. Urny okienkowe charakteryzuje czworokątny otwór w ściance. Niektóre $\mathrm{z}$ nich posiadają starannie wykonane, zdobione otwory wycięte przed wypaleniem naczynia, np. Kielary - grób 90, czy Tumiany - grób 32. Inne natomiast, Kielary - grób XXVII, posiadają okienka niezdobione czy też, Kosewo I - grób 410, Wólka Prusinowska - grób 109, niestarannie wykonane otwory (Voigtmann 1941: 44-45). Popielnice okienkowe posiadają otwory umieszczone zwykle w górnej części naczynia i reprezentują najczęściej formy garnkowate. Nie spotyka się czworokątnych okienek wśród naczyń z baniastym brzuścem

${ }^{11}$ Pomimo uchwyconej przewagi grobów bezpopielnicowych na cmentarzysku w Pieckach (7 grobów jamowych, 1 popielnicowy) należy wziąć pod uwagę, iż stanowisko to zostało najprawdopodobniej w znacznym stopniu zniszczone przez zabudowę wsi (Rudnicki 2004).

${ }^{12}$ Odmienny pogląd wyraził J. Okulicz, według którego na cmentarzyskach grupy olsztyńskiej miałby przeważać obrządek bezpopielnicowy (Okulicz 1973: 477).

${ }^{13}$ Badania przeprowadzone przez Instytut Archeologii Uniwersytetu Warszawskiego i Instytut Archeologii Uniwersytetu Łódzkiego w latach 2012-2015. 
i wyodrębnioną szyjką, które reprezentują wyłącznie grupę popielnic otworowych i posiadają otwory umieszczone w dolnej części naczynia.

Analogii do tych naczyń dopatrywano się na terenach saskich nad dolną Łabą i wśród wczesnych materiałów z cmentarzysk anglosaskich we wschodniej Anglii (Okulicz 1973: 477; Gąsowski 1985: 284). K. Voigtmann zarejestrował również pojedyncze przypadki naczyń z otworami na cmentarzysku rzędowym w Irlmauth, Kr. Regensburg, czy na wizygockim cmentarzysku w Sante Leocadia w Portugalii. Na terenie kultury Dollkeim/Kovrovo w dawn. Elchdorf, $\mathrm{Kr}$. Sammland odkryto popielnicę wiadrowata, posiadającą otwór w dolnej części naczynia (Voigtmann 1941: 43).

Przytaczane analogie naczyń saskich reprezentują zupełnie inne formy niż naczynia grupy olsztyńskiej ${ }^{14}$ (por. Roeder 1928; Waller 1937; Laux 1998: 78 ), poza tym posiadaja zwykle koliste otwory umieszczone w dnie naczynia, otwory w ściankach pojawiają się rzadziej (Roeder 1928: 149). Urny z otworami $\mathrm{w}$ dnie naczynia pojawiają się $\mathrm{w}$ materiałach grupy olsztyńskiej bardzo rzadko, np. Wyszembork, grób 207 (Szymański 2005: 163). Trudno wskazać mechanizmy, które doprowadziły do przyjęcia przez ludność grupy olsztyńskiej urn okienkowych i otworowych. Materiały, które można łączyć z Sasami, nie są zbyt czytelne wśród zabytków mazurskich. Na powiązania ze środowiskiem saskim lub anglosaskim mogą wskazywać niektóre formy zapinek lub elementy zdobienia ceramiki. Pewną poszlaką może być nazwa jednego z terytoriów plemiennych wczesnośredniowiecznych Prusów o nazwie Sasinia, wzmiankowana w źródłach krzyżackich. Plemię Sasinów miało zajmować obszar położony na zachód od terytorium Galindów, którego zasięg w dużym stopniu pokrywał się z obszarem osadnictwa grupy olsztyńskiej w późnym okresie wędrówek ludów. Nazwa ta miała rzekomo pochodzić od Sasów, którzy w późnym okresie wędrówek ludów mieli pojawić się na tym terytorium i tam się osiedlić (Gąsowski 1985: 274). Hipoteza ta koliduje jednak z przekazem wczesnośredniowiecznego kronikarza Galla Anonima, który nazwę Sasinia wywodził od Sasów, mających przybyć na te tereny dopiero za panowania Karola Wielkiego (768-814) (Gall Anonim: 106). Nazwę Sasinia (niemiecka nazwa: Sassen) wywodzi się również od pruskiego Sassins - zając, bez związku z jakimkolwiek obcym plemieniem (Knietz 1939: 45).

$\mathrm{Na}$ podstawie informacji zawartych $\mathrm{w}$ dzienniku F. E. Peisera (PM-A 1848/1-4) możemy stwierdzić, iż groby z późnego okresu wędrówek ludów zalegały na mniejszej głębokości niż obiekty z okresu wpływów rzymskich.

\footnotetext{
${ }^{14}$ Należy podkreślić, iż ta charakterystyczna grupa naczyń z obszarów saskich i anglosaskich wciąż nie doczekała się opracowania. Za podstawowe prace uchodzą publikacje sprzed drugiej wojny światowej (Buttel-Reepen 1925: 27; Roeder 1928; Waller 1937)
} 
Tabela 1. Wykaz obiektów odkrytych na cmentarzysku Kosewo I

\begin{tabular}{|l|c|}
\hline \multicolumn{2}{|c|}{ Liczba określonych obiektów na cmentarzysku Kosewo I } \\
\hline \multicolumn{2}{|c|}{ Badania M. Weigla 1891 } \\
\hline Groby ciałopalne popielnicowe & 24 \\
\hline Groby ciałopalne bezpopielnicowe & 5 \\
\hline Badania F. E. Peisera 1907-8 & 587 \\
\hline Groby ciałopalne popielnicowe & 106 \\
\hline Groby ciałopalne bezpopielnicowe & 5 \\
\hline Groby ciałopalne nieokreślone & 16 \\
\hline Zabytki luźne (z przypisnymi numerami w katalogu) & 9 \\
\hline Pozostałe obiekty & 752 \\
\hline Suma & 82 \\
\hline Brak danych (minimum) & $\mathbf{8 3 4}$ \\
\hline Szacowana całkowita liczba obiektów (minimum) & \\
\hline
\end{tabular}

niekiedy głębokość ta wynosiła tylko $10-15 \mathrm{~cm}$. od powierzchni gruntu. Zjawisko to uchwytne jest również na innych cmentarzyskach grupy olsztyńskiej (Bujack 1880: 32-33; Heydeck 1895: 42; Hollack, Peiser 1904: 13). W sprawozdaniu licznie pojawiają się wzmianki o zarejestrowaniu obiektów z późnego okresu wędrówek ludów w warstwie humusu lub tuż pod nią. Płytkie wkopywanie grobów doprowadziło do zniszczeniu wielu obiektów grupy olsztyńskiej przez orkę (PM-A 1848/1). Podobną sytuację uchwycono na cmentarzysku w Burdagu podczas badań z 2012 roku ${ }^{15}$. Dla odmiany w Kielarach głębokość zalegania grobów wynosiła nawet 60-80 cm (Hollack 1900: 162) czy $100 \mathrm{~cm}$ w Tumianach (Heydeck 1895: 42). Być może zwyczaj płytkiego umieszczania grobów grupy olsztyńskiej pochodzi z okresu wcześniejszego. Na cmentarzyskach schyłkowej kultury bogaczewskiej groby z fazy D miałyby być wykopywane na niewielkiej głębokości, co, podobnie jak w przypadku wielu grobów grupy olsztyńskiej, mogło być przyczyną ich zniszczenia w czasach nowożytnych (Bitner-Wróblewska 2000b: 161; 2001: 131-132). W niektórych przypadkach płytkie zaleganie grobów może jednakże wynikać z procesów przyrodniczych - erozji czy deflacji wzniesień.

\footnotetext{
${ }^{15}$ Niepublikowane badania z lat 2012-2015.
} 
W dzienniku F. E. Peisera pojawiały się również informacje o charakterze wypełniska grobu. Dzięki temu możemy stwierdzić, iż na cmentarzysku Kosewo I występowały groby ze spalenizną w wypełnisku (pozostałości stosu pogrzebowego) oraz bez spalenizny. Zjawisko występowania szczątków stosu uchwycono zarówno w grobach popielnicowych, jak i bezpopielnicowych. Sytuacja ta dotyczy zarówno grobów datowanych na okres wpływów rzymskich - groby: 24, 30, 42, 141, 142, 160, 205, 259, 262, 275, 290, 363, 408, 450, 587, 654, 660, 777, 781 jak i okres wędrówek ludów - groby: 34, 220, 227, 254, 374, 381, 442, 510, 512, 538, 786 (PMA- 1848/1-4). Dostępne źródła nie pozwalają jednak na dokonanie szczegółowych obserwacji i określenia stosunku występowania tych dwóch cech obrządku pogrzebowego względem siebie. Należy jednak podkreślić, iż obecność spalenizny w grobach popielnicowych należy do cech charakterystycznych dla obrządku pogrzebowego kultury bogaczewskiej ${ }^{16}$ (por. Szymański 2005: 91). Wśród obiektów grupy olsztyńskiej obecność pozostałości stosu pogrzebowego w grobach popielnicowych rejestruje się bardzo rzadko.

Na podstawie koordynatów zawartych w sprawozdaniu F. E. Peisera odtworzono plany cmentarzysk Kosewo I i Kosewo III. Braki w dokumentacji nie pozwalają jednak na lokalizację obiektów o numeracji powyżej 599 względem pozostałych grobów na cmentarzysku Kosewo ${ }^{17}$. Biorąc pod uwagę zarówno niepełny stan wiedzy o chronologii poszczególnych obiektów oraz luki w dokumentacji można jednak poczynić pewne spostrzeżenia w zakresie rozplanowania oraz stratygrafii horyzontalnej cmentarzyska. Na nekropoli Kosewo I nie stwierdzono odrębnych skupisk obiektów z okresu wpływów rzymskich i wędrówek ludów. Groby z okresu wpływów rzymskich występowały często obok pochówków datowanych na fazę E. Jedno wyraźne skupisko obiektów datowanych datowanych na fazy B2/C1-D zarejestrowano w północno-wschodniej części nekropoli. Jeśli przyjmiemy hipotezę o ciagłym użytkowaniu nekropoli od schyłku okresu wczesnorzymskiego po późny okres wędrówek ludów, to właśnie tę część cmentarzyska można by uznać za najwcześniejszą. Z dużą ostrożnością można zatem założyć, iż rozwój cmentarzyska następował w kierunku południowo-wschodnim, gdzie koncentruje się większość obiektów datowanych na okres wędrówek ludów.

\footnotetext{
${ }^{16} \mathrm{Na}$ cmentarzysku w Wyszemborku pozostałości stosu pogrzebowego zarejestrowano w 59\% grobów popielnicowych datowanych na okres wpływów rzymskich (Szymański 2005: 91).

${ }^{17}$ W kopiach dziennika F. E. Peisera brakuje stron z koordynatami Augenpunktu IV, od którego odmierzano położenie obiektów powyżej nr 599.
} 
Tabela 2. Porównanie wielkości wybranych cmentarzysk grupy olsztyńskiej

\begin{tabular}{|c|c|}
\hline Cmentarzysko & Liczba obiektów \\
\hline Babięta/Babienten, cmentarzysko I & co najmniej 461 \\
\hline Babięta/Babienten, cmentarzysko II & co najmniej 300 \\
\hline Bartlikowo/Bartlickhof & co najmniej 440 \\
\hline Bogaczewo/Kullabrücke & 443 \\
\hline Burdag/Burdungen** & co najmniej 271 \\
\hline Gąsior/Gonschor & 425 \\
\hline Jakubowo/Jakobsdorf & co najmniej 118 \\
\hline Kamień/Kamien & co najmniej 145 \\
\hline Kielary/Kellaren* & co najmniej 154 \\
\hline Kosewo/Kossewen, cmentarzysko I & co najmniej 834 \\
\hline Kosewo/Kossewen, cmentarzysko III* & 253 \\
\hline Leleszki/Lehlesken* & 45 \\
\hline Machary/Macharren & co najmniej 240 \\
\hline Miętkie/Mingfen, cmentarzysko I & co najmniej 865 \\
\hline Miętkie/Mingfen, cmentarzysko II & co najmniej 77 \\
\hline Muntowo/Alt Muntowen & co najmniej 257 \\
\hline Nikutowo/Nikutowen & co najmniej 437 \\
\hline Onufryjewo/Onufrigowen & co najmniej 586 \\
\hline Spychówko/Klein Puppen & co najmniej 301 \\
\hline Stare Kiejkuty/Alt Keykuth & co najmniej 110 \\
\hline Tumiany/Daumen* & co najmniej 300 \\
\hline Wawrochy/Wawrochen & co najmniej 159 \\
\hline Wólka Prusinowska/Pruschinowen Wolka* & co najmniej 179 \\
\hline Zalec/Salza & około 90 \\
\hline
\end{tabular}

* Cmentarzyska założone i funkcjonujące wyłącznie w fazie E

** Badania G. Bujacka (1884) dostarczyły 69 grobów. Weryfikacyjne badania z lat 2012-2015 doprowadziły do odkrycia kolejnych 202 grobów. 
We wschodniej strefie osadnictwa grupy olsztyńskiej, w której leżą cmentarzyska w Kosewie, kontynuowano zwykle użytkowanie nekropoli kultury bogaczewskiej. Do wyjątków należą tam nieliczne cmentarzyska zakładane i użytkowane wyłącznie w późnym okresie wędrówek ludów, takie jak Kosewo III czy Piecki. Groby z fazy E zwykle nie naruszały pochówków wcześniejszych, choć na cmentarzysku w Kosewie zdarzało się to dosyć często. Liczne przypadki zniszczenia grobów wcześniejszych przez obiekty z fazy E pozwalają przypuszczać, że część grobów z okresu wpływów rzymskich nie była oznaczona na powierzchni. Na podstawie dotychczasowych badań można stwierdzić, iż groby grupy olsztyńskiej tworzyły zwykle osobne strefy koncentracji, znajdujące się poza obszarem występowania grobów z okresu wpływów rzymskich lub nieznacznie się na niego nasuwając. Na cmentarzysku w Wyszemborku, jedynym dobrze przebadanym i zadokumentowanym cmentarzyskiem we wschodniej strefie grupy olsztyńskiej, zarejestrowano odrębne skupisko grobów z fazy $\mathrm{E} w$ stosunku do grobów z okresu wpływów rzymskich, odbijające się w stratygrafii horyzontalnej (Szymański 2005: 113). Sytuację taką zarejestrowano również na nekropolach $w$ Muntowie $^{18}$ (Nowakowski 2006: 216) czy Zalcu (Szymański 2006: 178). Na cmentarzysku w Spychówku groby bogaczewskie miały być oddzielone od grobów grupy olsztyńskiej brukiem kamiennym (Hollack, Peiser 1904: 19). Zjawisko to może świadczyć o widocznym oznaczeniu wcześniejszych grobów na powierzchni ziemi lub o przetrwaniu w świadomości ludności grupy olsztyńskiej żywej tradycji użytkowania danej nekropoli sięgającej jeszcze okresu wpływów rzymskich. Niewykluczone, iż wyraźnie wyodrębniające się skupiska grobów z późnego okresu wędrówek ludów pojawiały się na innych, wielofazowych cmentarzyskach we wschodniej strefie osadnictwa grupy olsztyńskiej. W nielicznych przypadkach obiekty grupy olsztyńskiej niszczyły wcześniejsze obiekty, np. w Miętkich (Okulicz 1973: 476) co odpowiada sytuacji na cmentarzysku Kosewo I.

Na uwagę zasługuje wielkość cmentarzyska Kosewo I. Pod tym względem nekropola ta wyraźnie wyróżnia się na tle innych cmentarzysk zachodniobałtyjskich z okresu wpływów rzymskich i okresu wędrówek ludów w północnowschodniej Polsce. Ogólna liczba ponad 800 grobów czyni to stanowisko jednym z największych cmentarzysk zachodniobałtyjskich w granicach Polski. Najbliższe terytorialnie nekropole z Zalca, Wyszemborka, czy Muntowa są wyraźnie mniejsze (patrz tabela 2). Zjawisko to oraz znaczna liczba bogato wyposażonych grobów z fazy E może świadczyć o wyjątkowej pozycji tego mikroregionu w późnym okresie wędrówek ludów oraz intensywnych kontaktach zamieszku-

\footnotetext{
${ }^{18}$ Autor opracowania podkreśla, iż jest to jednak hipoteza (Nowakowski 2004b: 216).
} 
jącej go ludności. Pod względem liczby importowanych przedmiotów, nekropola ta ustępuje wyłącznie cmentarzyskom w Tumianach i Kielarach, położonych jednak w zachodniej strefie osadnictwa grupy olsztyńskiej.

Brak pewnych danych odnośne liczby grobów z fazy E na mazurskich cmentarzyskach użytkowanych od okresu wpływów rzymskich uniemożliwia najczęściej określenie liczebności populacji użytkującej daną nekropolę. Stan badań nad mikroregionami z późnego okresu wędrówek ludów regionie jez. Juksty i Jez. Probarskiego nie pozwala na podobne ustalenia także w stosunku do cmentarzysk w Kosewie. Kompleksowo opracowany mikroregion w rejonie jeziora Salęt na Pojezierzu Mraggowskim dostarczył danych o czterech osadach, jednym cmentarzysku pewnym (Wyszembork st. IVa) i jednym hipotetycznym (Popowo Salęckie) z okresu wędrówek ludów skupionym wokół jednego jeziora. Mimo opracowania szacunkowej liczebności populacji użytkującej, cmentarzysko w Wyszemborku w okresie wpływów rzymskich, nie poczyniono podobnych ustaleń dla okresu wędrówek ludów (por. Szymański 2005: 106-111). W przypadku innych mikroregionów sytuację komplikuje dodatkowo fakt, iż nie mamy pewnych danych o faktycznej liczbie cmentarzysk w obrębie jednej miejscowości, a także o rzeczywistej ilości grobów na danej nekropoli. Dotyczy to szczególnie największych znanych nekropoli grupy olsztyńskiej w Kosewie i Miętkich. W zachodniej części osadnictwa grupy olsztyńskiej wśród nekropoli założonych $\mathrm{w}$ fazie $\mathrm{E}$ można zaobserwować cmentarzyska duże: jak Kielary czy Tumiany i małe, np. Leleszki, Bartołty Wielkie czy Waplewo (patrz tabela 2). Obserwacje te poczyniono na podstawie nekropoli przebadanych w całości lub w dużym stopniu. Mogą one jednak zostać podważone, gdyż dopiero weryfikacja niektórych stanowisk, przebadanych przez archeologów niemieckich przed drugą wojną światową, dostarcza danych o faktycznym stanie przebadania cmentarzyska. Z sytuacją tą można się zetknąć na przykładzie cmentarzyska w Tumianach, gdzie badania z lat 1969-1971 dostarczyły nieodkrytych wcześniej pochówków oraz grobów końskich (por. Dąbrowski 1975; Baranowski 1996). Podobne zjawisko zarejestrowano również na cmentarzysku w Lasowcu (dawn. Sternwalde) oraz Burdagu.

Wśród grobów popielnicowych grupy olsztyńskiej rejestruje się niekiedy przypadki przykrywania popielnic odwróconymi naczyniami misowatymi, zjawisko to zarejestrowano no. w Leleszkach grób 44. (Bujack 1880), Kamieniu (Szter 2010: 248) czy Zdorach (Hollack, Peiser 1904: ryc. 14, 17; Gaerte 1929: ryc. 208, 267). W kilku przypadkach odkryto pucharek na pustej nóżce służący jako przykrywka, np. Kosewo I, grób 269, Kosewo III, grób 82. Interesujące 
jest naczynie z Wyszemborka, grób 202, które posiadało w czaszy okienkowate wycięcie typowe dla popielnic (Szymański 2005: 85). Specyficzną odmianą pokrywek są tzw. naczynia talerzowate. Tę formę naczyń zarejestrowano także na cmentarzysku w Kosewie, grób 747. Naczynia talerzowate należą do form typowych dla późnego okresu wędrówek ludów na Mazurach (Szter 2010: 244). Uwagę zwraca fakt, iż egzemplarz z Kosewa posiada charakterystyczne wycięcie w krawędzi wylewu, które także należy do cech wyróżniających niektóre naczynia grupy olsztyńskiej w późniejszym odcinku fazy E (Voigtmann 1941: 39). Na cmentarzysku w Łężanach, st. IV, pow. kętrzyński odkryto popielnicę z wycięciem w krawędzi wylewu, przykrytą naczyniem talerzowatym, również posiadającym wycięcie (Wiśniewska 2014: 31). Zarówno urna, jak i przykrywka wykazują niezwykłe podobieństwo do zestawu naczyń z grobu 747 z Kosewa. Naczynia te, stanowią niewątpliwe świadectwo oddziaływań grupy olsztyńskiej na tereny położone poza jej północną granicą.

Zwyczaj przykrywania popielnic misami spotykany jest bardzo często na cmentarzyskach kultury bogaczewskiej z okresu wpływów rzymskich (Hollack, Peiser 1904: 14-15; Jaskanis 1974: 145). Wydaje się jednak, iż w grupie olsztyńskiej nie był tak popularny. Tym niemniej może uchodzić za świadectwo przetrwania pewnych elementów kultury duchowej oraz zwyczajów sepulkralnych ludności zamieszkującej Mazury w okresie wpływów rzymskich po późny okres wędrówek ludów. Niezwykły przypadek wystąpił w Popielnie, pow. Pisz, gdzie za przykrywkę służyła szklana czarka, datowana na VI wiek, pochodząca z warsztatu frankijskiego w północnej Galii (Nowakowski 2001: 89; Stawiarska 2003). Jest to obok pucharka typu Snartemo z Kosewa drugi przypadek odkrycia dobrze zachowanego naczynia szklanego na terenie grupy olsztyńskiej. Do wyjątkowych form przykrywek należy również ręcznie wykonane, gliniane naczynie zaopatrzone w cztery nóżki ze Zdor (Hollack, Peiser 1904: ryc. 14, 17; Gaerte 1929: ryc. 208a, 267). Jest to jedyny znany przypadek odkrycia podobnego naczynia na terenie grupy olsztyńskiej.

Interesującym zjawiskiem dotyczącym grobów bezpopielnicowych jest występowanie w nich pucharków na pustych nóżkach, które reprezentują najbardziej charakterystyczną dla grupy olsztyńskiej kategorię naczyń (Okulicz 1988; Nowakowski 1989). Egzemplarze z grobów grupy olsztyńskiej posiadają niekiedy ślady oddziaływania wysokiej temperatury, np. Piecki, pow. Mragowo, grób 1 (Rudnicki 2004: 269), co sugeruje ich obecność na stosie pogrzebowym i wyklucza rolę popielnicy. W pojedynczych przypadkach zarejestrowano jednak pochówki złożone właśnie w pucharkach, np. Kosewo I, grób 190, 321. 
Trudno jednoznacznie orzec, czy rola tych naczyń sprowadzała się do daru dla zmarłego, czy też naczynia te pojawiały się na stosach w wyniku nieznanych nam rytuałów pogrzebowych (Rudnicki 2004: 269; Szymański 2005: 85).

Warto przy tym zwrócić uwagę, iż w grobach jamowych grupy olsztyńskiej, zawierających szczątki stosu bardzo często spotyka się zabytki, noszące ślady przepalenia. Najprawdopodobniej zostały one złożone wraz ze zmarłym na stosie, a następnie ze szczątkami złożone do grobu. Przedmioty z grobów popielnicowych nie noszą śladów oddziaływania wysokiej temperatury. Zjawisko to, powszechnie wystapiło na cmentarzysku w Burdagu ${ }^{19}$. Przy obecnym stanie badań, trudno wyjaśnić tą różnorodność obrządku pogrzebowego.

W wielu grobach na cmentarzysku Kosewo I odkryto pojedyncze kamienie różnej wielkości. Zwykle znajdowały się one nad pochówkiem. W jednym przypadku - grób 184. udało się również uchwycić konstrukcję kamienną - skrzynię (Rudnicki 2010: 279). Obstawy i bruki kamienne należą do elementów spotykanych na cmentarzyskach kultury bogaczewskiej (Jaskanis 1974: 100-103), np. w Kruklankach (Stadie 1919), Wyszemborku (Szymański 2005) czy Bogaczewie-Kuli (Okulicz 1958). Na terenie grupy olsztyńskiej zwykle nie spotyka się podobnych zabiegów sepulkralnych. Należy jednak podkreślić, iż stan wiedzy na temat obrządku pogrzebowego grupy olsztyńskiej jest o wiele uboższy niż w przypadku kultury bogaczewskiej. Nie można zatem bezkrytycznie datować grobów pod kamieniami na okres wpływów rzymskich. W przypadku konstrukcji kamiennych takie datowanie wydaje się jednak uzasadnione, gdyż nie znamy żadnego potwierdzonego przypadku grobu w skrzyni kamiennej z fazy E na terenie grupy olsztyńskiej ${ }^{20}$.

$\mathrm{Na}$ cmentarzysku Kosewo I wystąpiły również obiekty niepełniące funkcji grobów, lecz być może związane z obrzędowością sepulkralną. Zarejestrowano dwa obiekty określone jako Brandstelle, autor badań - F. E. Peiser wyraźnie wyróżnia je spośród grobów. Nazwa wskazuje, iż zawierały one najprawdopodobniej spaleniznę w wypełnisku. Brak wymiarów nie pozwala jednak określić, czy obiekty te to pozostałości palenisk, stosów pogrzebowych czy też pełniły one inną funkcję. W obu obiektach nie zarejestrowano materiału zabytkowego. Obiekty związane z cmentarzyskiem, a niepełniące funkcji grobów uchwy-

\footnotetext{
${ }^{19}$ Niepublikowane wyniki badań z lat 2012-2014.

${ }^{20}$ Brak skrzyń kamiennych i płyt kamiennych nad grobami (Steindeckung) z okresu wędrówek ludów poświadczono na najpełniej przebadanych cmentarzyskach grupy olsztyńskiej w Tumianach (Heydeck 1895), Kielarach (Hollack, Bezzenberger 1900) oraz Wyszemborku (Szymański 2005). Grób 184 z cmentarzyska Kosewo I można natomiast dość pewnie datować na okres wpływów rzymskich ze względu na obecność w nim grotu broni drzewcowej (Rudnicki 2010a: 279).
} 
cono również na innych mazurskich nekropolach datowanych na późny okres wędrówek ludów. Strefy kremacji zwłok znajdowały się jednak zwykle poza strefą występowania grobów. Obiekty, będące zapewne pozostałościami stosów ciałopalnych odkryto na cmentarzyskach w Bartlikowie (Kemke 1900: 109), Bogaczewie (Okulicz 1958: 110-111), Paprotkach-Kolonii (Karczewska, Karczewski 2007: 203) czy Wyszemborku (Szymański 2005: 95). Podkreślić należy jednak niepewny związek tych obiektów z grupą olsztyńską, gdyż wspomniane nekropole użytkowane były również przez ludność kultury bogaczewskiej Obiekty odkryte na cmentarzysku Kosewo I, pojawiły się w strefie występowania grobów, co raczej wyklucza możliwość, iż pełniły funkcje stosów w okresie wędrówek ludów. Podobne obiekty zarejestrowane na cmentarzysku w Kamieniu, również występowały w strefie składania grobów (Szter 2010: 248). Prawdopodobnie były one pozostałościami palenisk, związanych z obrzędami ku czci zmarłych. Obiekty pełniące najprawdopodobniej taką funkcję uchwycono na wspominanym wielokrotnie cmentarzysku w Wyszemborku, gdzie natrafiono na pozostałości stosów pogrzebowych oraz podłużne obiekty zawierające spaleniznę, szczątki kości zwierzęcych, a także fragmenty naczyń glinianych oraz zabytki metalowe. Jamy te mogą być pozostałością po obiektach związanych z ceremoniami pogrzebowymi o nieuchwytnym jeszcze charakterze (Okulicz 1988: 116-121) natomiast na obiekty będące najprawdopodobniej paleniskami natrafiono na cmentarzysku w Zalcu (Szymański 2004: 177).

Nie zarejestrowano na cmentarzyskach w Kosewie grobów końskich, które występują na Mazurach w okresie wpływów rzymskich oraz w okresie wędrówek ludów. Stanowią one element charakterystyczny dla zwyczajów pogrzebowych ludności kręgu zachodniobałtyjskiego (Jaskanis 1966; 1968; Gręzak 2007). Na cmentarzyskach grupy olsztyńskiej groby końskie pojawiają się częściej niż w poprzedzającej ją kulturze bogaczewskiej (Jaskanis 1968; Baranowski 1996). Groby końskie zarejestrowano licznie na cmentarzysku w Tumianach, a także w Zalcu czy Wyszemborku. Polskie, powojenne badania weryfikacyjne na cmentarzysku w Tumianach wykazały, że badacze niemieccy często nie docierali do grobów końskich, które zalegały o wiele głębiej niż pochówki ludzkie (Baranowski 1996; 2004: 159). Na nekropoli w Tumianach uchwycono również zwyczaj ćwiartowania koni, który przypisywano wpływom awarskim (Baranowski 1996: 163). Trudno jednak bezkrytycznie przyjąć tę hipotezę, gdyż pochówki poćwiartowanych koni spotykane są na obszarach zachodniobałtyjskich już w okresie wpływów rzymskich, w tym w kulturze bogaczewskiej poprzedzającej osadnictwo grupy olsztyńskiej na Mazurach (Jaskanis 1968: 98; 
1974: 170-171; Gręzak 2007: 360-361). Zwyczaj ten spotykany w grobach datowanych na późny okres wędrówek ludów może stanowić więc kontynuację wcześniejszej tradycji.

Cmentarzysko w Kosewie nie dostarczyło znalezisk broni w zespołach datowanych na fazę E. Brak elementów uzbrojenia w grobach jest jedną z najbardziej charakterystycznych cech obrządku pogrzebowego grupy olsztyńskiej. Do wyjątków należy grób 120. z Tumian w którym odkryto pojedynczy grot włóczni (Heydeck 1895: 62; Jakobson 2009: tabl. 69). Długi nóż z Kielar, grób 6, określany jako miecz jednosieczny (Ehrlich 1931: 25-26; Urbańczyk 1978: 110) nie pełnił najprawdopodobniej funkcji bojowych. Znacznie różni się on długością (około $30 \mathrm{~cm}$ ) i formą od popularnych w Europie Zachodniej i Północnej mieczy jednosiecznych typu sax. B. Ehrlich określił ten zabytek jako krótki miecz - Kurzschwert (Ehrlich 1931: 25), wydaje się jednak, iż właściwym określeniem byłaby, przytoczona wcześniej nazwa - długi nóż. Nóż ten wraz z pochwą z bogato ornamentowaną okładziną ze srebrnej blachy mógł być świadectwem wysokiej pozycji społecznej zmarłego. W omawianym grobie znaleziono bowiem trzy ostrogi nitowe zdobione stempelkami, tutulowatą zapinkę tarczowatą, zapinkę szczebelkową późnej formy, zapinkę płytkową typu Novi Banovci-Kielary oraz srebrne okucie zdobione ornamentem łuskowym (Hollack 1900: 169; Jakobson 2009: tabl. 110).

Do interesujących zabytków należą $U$ - kształtne okucia z Miętkich, groby 45 i 629 oraz Wólki Prusinowskiej, grób 92 Pierwsze z nich mierzy 7,2 cm rozpiętości, drugie $6,7 \mathrm{~cm}$ (Jakobson, Spuścizna). Zbliżone okucie odkryto również na cmentarzysku Kosewo III (Gładki, Stokłosa 2015b: 126). Okucia te mogły pełnić funkcję trzewików pochew mieczy ${ }^{21}$, dołączając tym samym do niewielkiej grupy zabytków wiązanych z elementami uzbrojenia. Brak broni w grobach grupy olsztyńskiej nasuwa skojarzenia z kręgiem gockim (Bitner-Wróblewska 2004: 39). Wśród Gotów dopatrywano się niekiedy twórców grupy olsztyńskiej (Heydeck 1895: 70; Fromm 1932: 281-282, Bujak 1948: 45). Brak uzbrojenia $\mathrm{w}$ grobach zauważono również $\mathrm{w}$ grobach kultury bogaczewskiej z fazy $\mathrm{D}$, w której kultura ta jednak, mało czytelnie rysuje się w materiale archeologicznym (Bitner-Wróblewska 2000b: 161; 2004: 39). Przy obecnym stanie badań trudno jednoznacznie stwierdzić, czy brak broni w zespołach z fazy D spowodowany był obrządkiem zarzucającym deponowanie uzbrojenia w ziemi, wynikającym z silnego wpływu ze strony kultur gockich czy też wynika z możliwości poznawczych materiałów z tego okresu. Gockie wpływy w zakresie omawia-

${ }^{21} \mathrm{~W}$ kartotece F. Jakobsona, na karcie z inwentarzem grobu 626 z Miętkich, obok wspomnianego U- kształtnego okucia znajduje się dopisek: Endebeschlag von Schwertscheide 
nej cechy obrządku pogrzebowego sięgnąć mogły również kultury sudowskiej (Bitner-Wróblewska 2004). Wspomnieć należy przy tym, iż w późnym okresie wędrówek ludów powszechnie spotyka się broń w grobach grupy elbląskiej, a na obszarach sambijsko-natangijskich praktykowano deponowanie broni w grobach, aż po wczesne średniowiecze (por. Kulakov 1990; Nowakowski 1996). W okresie funkcjonowania grupy olsztyńskiej, kultura wielbarska już nie istnieje, brak więc możliwości oddziaływań z kręgu gockiego płynących z najbliższego sąsiedztwa. Relikty kultury wielbarskiej w rejonie dolnej Wisły, które można datować na schyłek fazy $\mathrm{D}$, reprezentowane między innymi przez stanowiska w Bornicach czy Pruszczu Gdańskim mogły w ograniczonym zakresie wywierać wpływ na ludność zachodniobałtyjską. Należy przy tym podkreślić, iż podobnie jak w kulturze wielbarskiej wśród zabytków metalowych spotykanych w zespołach grupy olsztyńskiej zdecydowanie dominują przedmioty wykonane z brązu. Zjawisko to także potwierdzają materiały z cmentarzysk w Kosewie. Niewykluczone, iż ludność grupy olsztyńskiej, zasiedlając tereny nad górną Łyną natrafiła na epigonów kultury wielbarskiej. Trudno jednak przypuszczać, iż w wyniku takich kontaktów doszłoby do zaadaptowania zwyczaju nieskładania broni do grobów na obszarze całej grupy olsztyńskiej.

Rozwiązanie tego problemu może przynieść hipoteza, według której bałtyjska ludność kultury bogaczewskiej wywędrowała wcześniej wraz z plemionami gockimi. Po latach współżycia z nimi powraca na Mazury do ziemi swoich przodków stanowiąc trzon późniejszej grupy olsztyńskiej. Zjawisko to mogło być spowodowane wyemigrowaniem ludności tej kultury wraz z plemionami gockimi na obszary nadczarnomorskie lub naddunajskie u schyłku okresu późnorzymskiego (Gaerte 1929: 308-311; Nowakowski 1989: 120-121). W świetle materiałów, które poświadczają niemal całkowity zanik pochówków z fazy D na cmentarzyskach tej kultury, można przypuszczać, iż ruch ten miałby charakter ogólnoplemienny i zorganizowany. Epigoni ludności kultury bogaczewskiej, którzy pozostali na terenie Pojezierza Mazurskiego, chowali zapewne swoich zmarłych w płytkich grobach, które mogły być niszczone w czasach późniejszych poprzez rolnicze użytkowanie gruntów, stąd większość zabytków z wczesnego okresu wędrówek ludów odkryta została w kontekście luźnym (Bitner-Wróblewska 2000b). Biorąc pod uwagę różnicę chronologiczną między momentem zaniku kultury bogaczewskiej a powstaniem grupy olsztyńskiej, należałoby się liczyć z reemigracją 3-4 pokolenia. Być może wówczas nastąpiło zarzucenie zwyczaju deponowania broni $w$ grobach pod wpływem kultury gockiej. Jakkolwiek źródła pisane notują przypadki podobnych reemigracji, jak np. Herulów z Kotliny Karpackiej lub Sasów z Brytanii czy Italii, to brak zupełnie źródeł 
pisanych i archeologicznych, poświadczających wędrówkę plemion zachodniobałtyjskich na południe. Przyjmuje się, że owa reemigracja Bałtów mogła mieć charakter dwufazowy. Pierwsza, mniejsza grupa miałaby przybyć na Mazury około połowy $\mathrm{V}$ wieku, natomiast druga, stanowiąca trzon plemienia na początku VI wieku (Nowakowski 1989b: 121). Interesujący jest w tym kontekście fragment Kroniki Mistrzów Pruskich, przełożonej z niemieckiego przez Marcina Muriniusa, wydanej w Toruniu w 1582 roku. W akapicie poświęconym najdawniejszym dziejom plemion pruskich autor przytacza legendę, wedle której grupa Germanów przybywa po walkach w Italii na ziemie Prusów i osiedla się na nich.

[...] Obywatele ziemie tej oni starzy Prusowie ludzie byli prości (jako w pogaństwie). Do tych w pustynie potem Cymbrowie, Getae lub Gepidowie, już długimi wojnami, które we Włoszech wiedli, spracowani przyszli ze wszystkim sprzętem i dobytkiem, a z nimi się zbraciwszy osadzać się jęli $[\ldots]^{22}$.

Tekst ten, jakkolwiek nieposiadający wartości historycznej, zwraca uwagę na możliwość istnienia zakorzenionej w świadomości Prusów informacji o przybyciu na ich tereny ludu germańskiego (Gotów/Gepidów?) z południa Europy. $\mathrm{Na}$ związki ziem zachodniobałtyjskich z Italią ostrogocką wskazuje zachowany list Teodoryka Wielkiego do Estiów, zredagowany najprawdopodobniej przez Kasjodora około 514-517 roku, zawierający podziękowanie za bursztyn przesłany królowi Ostrogotów (Kolendo 1990: 97).

W świetle dostępnych źródeł trudno jednoznacznie potwierdzić hipotezę o wywędrowaniu i powrocie Galindów na Mazury, kiedy to przynieśliby ze sobą gockie zwyczaje. Bez wątpienia istniały jednak kontakty ludności bałtyjskiej zamieszkującej Mazury z kulturami archeologicznymi kręgu gockiego. W okresie wpływów rzymskich sąsiedztwo między tymi dwoma różnymi etnicznie ludami miało prawdopodobnie pokojowy charakter (Nowakowski 1989b; Andrzejowski, Cieśliński 2007: 309). Takie stosunki mogły zaowocować udziałem zachodniobałtyjskich drużyn w gockich przedsięwzięciach w okresie wędrówek ludów. Hipotetyczny udział w gockich wyprawach wojennych mógł więc $\mathrm{w}$ ograniczonym stopniu zaowocować przejęciem gockich zwyczajów sepulkralnych (por. Bitner-Wróblewska 2004).

Inwentarze grobowe z Mazur, datowane na późny okres wędrówek ludów wyróżniają się często bogactwem wyposażenia na tle kręgu zachodniobałtyjskiego. Bardzo licznie pojawiają się elementy stroju, takie jak: zapinki, meta-

${ }^{22}$ Fragment Kroniki Mistrzów Pruskich M. Muriniusa z 1582 roku, źródło: http://www.domwarminski.pl/b content/view/431/582. 
lowe elementy pasów, ozdoby, pierścionki, bransolety, zawieszki czy paciorki, a także przedmioty codziennego użytku. W wielu przypadkach są to cenne importowane przedmioty. Zjawisko to od dawna budziło zainteresowanie wśród badaczy. Przedmioty składane do grobów świadczyły o zamożności i rozległych kontaktach ludności grupy olsztyńskiej. Wciąż niejasne sąźródła tego bogactwa, widocznego w inwentarzach grobowych. Szczególnym świadectwem kontaktów dalekosiężnych, czytelnym na podstawie materiałów archeologicznych są zapinki płytkowe (Bügelfibeln). Fibule te na obszarach zachodniej Europy służyły do spinania sukni i kaftanów (Martin 1994; 1995; Bemmann 2009). Liczne znaleziska z grobów szkieletowych na cmentarzyskach rzędowych kręgu merowińskiego pozwalają precyzyjnie zrekonstruować sposób ich noszenia. Ze względu na ciałopalny obrządek pogrzebowy nie można na Mazurach poczynić podobnych obserwacji. Według E. Šturmsa zapinki płytkowe miałyby występować zwykle w grobach kobiecych (Šturms 1950: 21). Spostrzeżenie to, badacz ten poczynił na podstawie współwystępowania fibul płytkowych z przedmiotami typowymi dla pochówków kobiet, tj. z przęślikami, koliami paciorków. W grobach męskich znajdować się miały zapinki o rodzimej zachodniobałtyjskiej proweniencji, czyli fibule kuszowate zdobione pierścieniami z nacinanego drutu czy zapinki szczebelkowe (Armbrustsprossenfibeln) oraz ostrogi (Šturms 1950: 21). Hipoteza ta oparta była na analizie materiału zabytkowego z badań sprzed drugiej wojny światowej, kiedy to badania antropologiczne szczątków kostnych, pochodzących z cmentarzysk ciałopalnych, należały do rzadkości. Tezę tę należałoby potwierdzić poprzez analizę zespołów grobowych oraz równoległe badania szczątków kostnych. Postulat ten odnosi się jednak do polskich badań powojennych, gdyż większość materiałów zabytkowych i kostnych z badań przedwojennych uległa rozproszeniu w czasie ostatniej wojny światowej.

Trudno stwierdzić różnice społeczne na podstawie formy grobu, w którym pochowany został zmarły. Zarówno w grobach jamowych jak i popielnicowych znajdują się bogato i ubogo wyposażone pochówki. $Z$ rezerwą należy się również odnieść do przypuszczenia $Ł$. Okulicz-Kozaryn (1983: 73), iż na obszarze grupy olsztyńskiej praktykowano zwyczaj zakładania oddzielnych cmentarzysk dla bogatej i biednej ludności. Wskazywane jako przykład nekropoli bogatych, stanowiska w Tumianach, Kosewie i Kielarach zawierają zarówno pochówki bogato wyposażone, jak i całkowicie pozbawione wyposażenia. Badaczka ta w późniejszej pracy przypuszczała, iż na nekropolach grupy olsztyńskiej mogły istnieć osobne sektory, w których chowano bogatych i biednych zmarłych (Okulicz-Kozaryn 1997: 137). Wobec braku analizy rozplanowania większości 
cmentarzysk trudno potwierdzić tę hipotezę. Należy jednak podkreślić, że znamy nekropole zdecydowanie ubogie, np. Wyszembork (por. Szymański 2005) czy Burdąg (por. Bujack 1884).

Brak jest dokładnych danych, ile pochówków mogły zawierać groby na cmentarzyskach w Kosewie, jak i na innych nekropolach grupy olsztyńskiej. Należy tu uwzględnić po raz kolejny metodykę badań przedwojennych, kiedy to liczba pochówków w grobach nie była rejestrowana ze względu na brak analizy antropologicznej. Podczas badań wykopaliskowych w Kosewie zarejestrowano jednak skupiska grobów, które być może można interpretować jako skupiska rodzinne. Wyraźne skupiska, mogące świadczyć składaniu w danym miejscu szczątków zmarłych należących do danej rodziny odnotowano także, np. w Leleszkach (Bujack 1880a: 32-33), Wyszemborku (Szymański 2005: tabl. XXXVI) czy Burdagu ${ }^{23}$.

W najpóźniejszym okresie rozwoju grupy olsztyńskiej obserwuje się wyraźne zubożenie inwentarzy grobowych oraz powszechną degenerację wcześniejszych form zabytków. Zjawisko to szczególnie czytelne jest wśród zapinek płytkowych, gdzie występuje stopniowe zubożenie i zanik zdobienia oraz uproszczenie produkcji. Dostrzegalna jest również miniaturyzacja przedmiotów składanych do grobów. Niemiecki archeolog Carl Engel łączył ten fakt z paralelnymi zjawiskami uchwytnymi również na obszarach nadniemeńskich. Badacz ten dostrzegając wyraźną degenereację zabytków charakterystycznych rozwiniętego okresu wędrowek ludów mówił nawet o odrębnej westmasurische Miniaturkultur datowaną na Jüngste heidnische Zeitalter, tj. okres pomiędzy późnym okresem wędrówek ludów a przybyciem na Mazury Krzyżaków (Engel 1939: 48-51). Przyczyną tak późnego datowania był niewątpliwie brak dobrze datowanych znalezisk sepulkralnych na Mazurach z okresu między VII a XIII wiekiem. Mimo słusznego spostrzeżenia C. Engla, dotyczącego zmian form i wielkości ozdób u schyłku okresu wędrówek ludów, tak późne datowanie należy jednak wykluczyć.

Schyłek grupy olsztyńskiej wiąże się z zanikiem uchwytnego archeologicznie obrządku pogrzebowgo. Zmiana formy obrządku nie dotyczyła zapewne ciałopalenia, które rejestruje się we wczesnym średniowieczu u plemion pruskich. Źródła pisane wskazują, iż inhumacja była obca Prusom, którzy w kwestii ciałopalenia byli szczególnie konserwatywni (Labuda 1961: 86; Sabaciński 2002: 209-210). Zmiana obrządku pogrzebowego polegała najprawdopodobniej na odmiennej formie składania pochówku. Niewykluczone, iż zintensy-

${ }^{23}$ Niepublikowane badania z lat 2012-2015. 
fikowane wpływy słowiańskie od schyłku VII wieku doprowadziły do zaadaptowania przez ludność grupy olsztyńskiej słowiańskich elementów bezcmentarzyskowej obrzędowości sepulkralnej. Jako przykład przedstawiano notowany przez Nestora rytuał polegający na składaniu prochów zmarłych w urnach na słupach stojących przy rozstajach dróg, który współcześnie najprawdopodobniej nie mógłby zostać zarejestrowany metodami archeologicznymi (Nowakowski 2004a: 416). Nie ma jednak pewności, czy zaakceptowano właśnie tę, czy też podobną formę obrządku pogrzebowego. Inną możliwość nasuwa odkrycie pozostałości obrządku związanego z warstwowymi pochówkami na terenie grodzisk tzw. pochówki typu Czarny Las (Wróblewski 2000; Sabaciński 2002). Analogię do tej formy pochówków również dostarczają tereny Słowiańszczyzny (Wróblewski 2002: 279-280). Inna hipoteza wskazywała na możliwość adaptacji wschodniosłowiańskiego zwyczaju polegającego na składaniu pochówków w osadach, pod klepiskami ziemianek czy na cmentarzyskach typu Alt Käbelich (Wróblewski, Nowakiewicz, Bogucki 2003: 64). Sugerowano również możliwość przejęcia jaćwieskiego obrządku pogrzebowego, którego świadectwem są cmentarzyska warstwowe typu Burdyniszki (por. Nowakowski 1988: 119-123; Wróblewski, Nowakiewicz, Bogucki 2003: 64). Cmentarzyska warstwowe tzw. Aschenplätze, są rejestrowane również w okresie późniejszym na terenach wczesnośredniowiecznego osadnictwa pruskiego (por. Wróblewski 2006a).

Brak jest przesłanek, by sądzić, iż zanik materiałów datowanych na VIII wiek i później wiąże się z fizyczną eliminacją ludności grupy olsztyńskiej wskutek najazdów czy klęski naturalnej. Nie należy jednak wykluczyć możliwości porzucenia nekropoli i wyemigrowania części ludności na inne tereny. Nieuchwytne są bowiem mechanizmy zasiedlenia zachodnich terenów wczesnośredniowiecznego osadnictwa pruskiego. Datowane na późny okres wędrówek ludów dwa skupiska osadnicze na południowo-zachodnich rubieżach kręgu zachodniobałtyjskiego, czyli grupa elbląska i olsztyńska w niewielkim stopniu pokrywają się $\mathrm{z}$ wczesnośredniowiecznym osadnictwem pruskim sięgającym w X wieku obszarów Ziemi Chełmińskiej i Dolnego Powiśla, lecz zapewne odegrały istotną rolę w zasiedleniu tych obszarów (por. Engel 1935: ryc. 54, 99; Wróblewski 2006b; 2007). Być może na przełomie VII/VIII w. miała miejsce migracja ludności grupy olsztyńskiej w kierunku zachodnim, która doprowadziła do porzucenia użytkowanych wcześniej nekropoli, podobnie jak miało to miejsce u schyłku okresu późnorzymskiego w przypadku kultury bogaczewskiej. Także na cmentarzysku I w Kosewie nie zarejestrowano materiałów późniejszych niż datowane na VII w. Być może nekropola ta została wówczas porzuco- 
na lub zmieniono formę składania pochówku. Odpowiedź na pytanie o schyłek użytkowania cmentarzysk grupy olsztyńskiej przyniosą być może współczesne badania, które pozwolą także rzucić światło na inne zagadnienia związane z grupą olsztyńską, należącą do najmniej znanych jednostek kulturowych w pradziejach dzisiejszych ziem polskich.

dr Mirosław Rudnicki

Uniwersytet Łódzki

Wydział Filozoficzno-Historyczny

Instytut Archeologii

ul. Uniwersytecka 3

90-137 Łódź

\section{Bibliografia}

Źródła

Gall Anonim, Kronika Polska, przekład R. Grodecki, Wrocław 1982.

Jakobson Spuścizna, Spuścizna naukowa Feliksa Jakobsona przechowywana w Latvijas Nacionālais Vēstures Muzejs w Rydze.

PM-A 1848/1-4, Ortsakte Kossewen przechowywana w Prussia-Museum Archiv w Museum für Vor- und Frühgeschichte w Berlinie.

Opracowania

Åberg N. (1919), Ostpreußen in der Völkerwanderungszeit, Uppsala-Leipzig.

Andrzejowski J., Cieśliński A. (2007), Germanie i Battowie u schyłku starożytności. Przyjazne zwiqzki, czy wrogie sqsiedztwo, [w:] Kultura bogaczewska w 20 lat później. Materiały z konferencji, Warszawa 26-27 marca 2003, red. A. Bitner-Wróblewska, Państwowe Muzeum Archeologiczne w Warszawie, Stowarzyszenie Naukowe Archeologów Polskich Oddział w Warszawie, Warszawa, s. 279-319.

Antoniewicz J. (1952), (rec.) E. Šturms ,, Die etnische Deutung der masurgermanischen Kultur", Contributions of Baltic University, nr 31, Pinneberg 1947, „Sprawozdania PMA”, t. IV, z. 3-4, s. 215-220.

Baranowski T. (1996), Pochówki koni z Tumian w woj. olsztyńskim, „Archeologia Polski”, t. 41, z. 1-2, s. 65-130.

Baranowski T. (2004), Awarowie na Mazurach, [w:] Hereditatem Cognoscere. Studia $i$ szkice dedykowane Profesor Marii Miśkiewicz, red. Z. Kobyliński, Wydział Nauk Historycznych i Społecznych Uniwersytetu Kardynała Stefana 
Wyszyńskiego, Państwowe Muzeum Archeologiczne, Instytut Archeologii Uniwersytetu Warszawskiego, Warszawa, s. 157-164.

Bitner-Wróblewska A. (2000), Early Migration Period in the Mazurian Lakeland - phantom or reality?, [w:] Die spätrömischen Kaiserzeit und die frühe Völkerwanderungszeit in Mittel- und Osteuropa, red. M. Mączyńska, T. Grabarczyk, Wydawnictwo Uniwersytetu Łódzkiego, Łódź, s. 153-167.

Bitner-Wróblewska A. (2001), From Samland to Rogaland. East-West connections in the Baltic basin during the Early Migration Period, Państwowe Muzeum Archeologiczne, Warszawa.

Bitner-Wróblewska A. (2005), Suwalscy „pacyfiści”. Wpływ Gotów na obrzqdek pogrzebowy mieszkańców Suwalszczyzny w okresie wędrówek ludów?, [w:] Europa Barbarica. Ćwierć wieku archeologii w Masłomęczu, red. P. Łuczkiewicz, M. Gładysz-Juścińska, M. Juściński, B. Niezabitowska, S. Sadowski, Monumenta Studia Gothica, t. IV, UMCS, Lublin, s. 33-42.

Bitner-Wróblewska A. (2008), Śladami kolekcji Prussia-Museum (1943-2008), [w:] Archeologiczne księi inwentarzowe dawnego Prussia Museum. Die archäologischen Inventarbücher aus dem ehemaligen Prussia-Museum. Археологические инвентарные книги бывщего музея „Пруссия”, red. A. Bitner-Wróblewska, Aestiorum Hereditas, t. I, Archiwum Państwowe w Olsztynie, Olsztyn, s. 46-61.

Bujack G. (1880), Das Gräberfeld zu Reussen, Kr. Angerburg und zu Lehlesken, Kr. Ortelsburg, „Sitzungsberichte der Altertumsgesellschaft Prussia”, t. 5, s. $30-33$.

Bujack G. (1884), Vier Gräberfelder des sogen. Mittleren Eisenalters, „Sitzungsberichte der Altertumsgesellschaft Prussia", t. 9, s. 146-152.

Bujak F. (1948), Wenedowie na wschodnich wybrzeżach Battyku, Instytut Bałtycki, Gdynia-Bydgoszcz-Szczecin.

Buttel-Reepen H. (1925), Über Fensterurnen, „Oldenburger Jahrbuch”, t. 29, s. $328-400$.

Buttel-Reepen H. (1927), Über Fensterurnen II, „Oldenburger Jahrbuch”, t. 31, s. $231-259$.

Dąbrowski K. (1975), Archäologische Untersuchungen in Tumiany, Kr. Olsztyn, „Zeitschrift für Archäologie”, t. 9, s. 265-280.

Ebert M. (1926), Truso, „Schriften der Königsberger Gelehrten Gesellschaft”, Geisteswissenschaftliche Klasse, 3/1, Berlin, t. I, s. 71-81.

Ehrlich B. (1931), Schwerter mit silberbeschlagenen Scheiden von Benkenstein, Kr. Elbing und einige west- und ostpreussiche vergleichstücke, „Sitzungsberichte der Altertumsgesellschaft Prussia”, t. 29, s. 16-46.

Engel C. (1932), Die Bevölkerung Ostpreußens in vorgeschichtlicher Zeit, Königsberg.

Engel C. (1935), Aus ostpreußischer Vorzeit, Königsberg. 
Engel C. (1939), Das jüngste heidnische Zeitalter in Masuren, „Sitzungsberichte der Altertumsgesellschaft Prussia", t. 33, s. 41-57.

Fromm L. (1932), Die Goten im Kreise Allenstein, „Unsere Heimat”, t. 24, s. 281-282.

Gaerte W. (1929), Urgeschichte Ostpreußens, Königsberg.

Gąsowski J. (1985), Kultura pradziejowa na ziemiach polskich - zarys, PWN, Warszawa.

Gładki M., Stokłosa K. (2015a), Wyniki badań ratowniczych przeprowadzonych w 2014 roku na cmentarzysku z okresu wędrówek ludów w Kosewie st. 2 (Kossewen III), [w:] Kosewo. Archiwalne cmentarzysko z okresu wędrówek ludów Kossewen III. Badania w roku 2014, red. A. Jaremek, Fundacja Dajna im. Jerzego Okulicza-Kozaryna, Warszawa, s. 25-34.

Gładki M., Stokłosa K. (2015b), Katalog zabytków, [w:] Kosewo. Archiwalne cmentarzysko z okresu wędrówek ludów Kossewen III. Badania w roku 2014, red. A. Jaremek, Fundacja Dajna im. Jerzego Okulicza-Kozaryna, Warszawa, s. $95-128$.

Gręzak A. (2007), Groby koni na cmentarzyskach kultury bogaczewskiej, [w:] Kultura bogaczewska w 20 lat później. Materiały z konferencji, Warszawa 26-27 marca 2003, red. A. Bitner-Wróblewska, Państwowe Muzeum Archeologiczne w Warszawie, Stowarzyszenie Naukowe Archeologów Polskich Oddział w Warszawie, Warszawa, s. 353-367.

Hilberg V. (2009), Masurische Bügelfibeln. Studien zu den Fernbeziehungen der völkerwanderungszeitlichen Brandgräberfelder von Daumen und Kellaren. Daumen und Kellaren - Tumianuy i Kielary, Band 2, hrsg. A. Bitner-Wróblewska, C. von Carnap-Bornheim, V. Hilberg, W. Nowakowski, Schriften des Archäologischen Landesmuseums, t. 9, Neumünster.

Hollack E., Bezzenberger A. (1900), Das Gräberfeld bei Kellaren im Kreise Allenstein, „Sitzungsberichte der Altertumsgesellschaft Prussia”, t. 21, s. 161-195.

Hollack E., Peiser F. (1904), Das Gräberfeld von Moythienen, Königsberg.

Jakobson F. (2009), Die Brandgräberfelder von Daumen und Kellaren im Kreise Allenstein, Ostpreussen. Daumen und Kellaren-Tumiany i Kilary, Band 1, hrsg. A. Bitner-Wróblewska, C. von Carnap-Bornheim, V. Hilberg, W. Nowakowski, Schriften des Archäologischen Landesmuseums, t. 9, Neumünster.

Jaskanis J. (1968), Pochówki z końmi na cmentarzyskach protojaćwieskich z okresu rzymskiego i wędrówek ludów, „Rocznik Białostocki”, t. VIII, s. 77-111.

Jaskanis J. (1974), Obrzqdek pogrzebowy zachodnich Battów u schyłku starożytności [I-V w.n.e.], Biblioteka Archeologiczna, t. 23, Ossolineum, Wrocław.

Juga A., Ots M., Szymański P. (2003), Über die Vorteile der Bildung einer „, didaktischen Kollektion”. Materialien der Bogaczewo-Kultur und OlsztynGruppe in Ajaloo Instituut in Tallinn (Estland), [w:] Antyk i Barbarzyńcy. 
Księga dedykowana Profesorowi Jerzemu Kolendo, red. A. Bursche, R. Ciołek, Instytut Archeologii Uniwersytetu Warszawskiego, Warszawa, s. $205-218$.

Kemke H. (1900), Das Gräberfeldv. Bartlickshof, „Schriften der Physikal-Ökonomischen Gesellschaft", t. XLI, s. 108-134.

Karczewska M., Karczewski M. (2007), Uwagi o obrzqdku pogrzebowym kultury bogaczewskiej na przykładzie cmentarzyska w Paprotkach-Kolonii, [w:] Kultura bogaczewska w 20 lat później. Materiały z konferencji, Warszawa 26-27 marca 2003, red. A. Bitner-Wróblewska, Państwowe Muzeum Archeologiczne w Warszawie, Stowarzyszenie Naukowe Archeologów Polskich Oddział w Warszawie, s. 195-217.

Knietz G. (1939), Von Grenzen und Landwehren in der altpreußischen Landschaft Sassen, „Alt Preußen”, t. 4/2, s. 44-47.

Kowalski J. (1991), Z badań nad chronologia okresu wędrówek ludów na ziemiach zachodniobattyjskich (faza E), [w:] Archeologia Bałtyjska. Materiały z konferencji. Olsztyn, 24-25 kwietnia 1988 roku, Ośrodek Badań Naukowych im. Wojciecha Kętrzyńskiego, Olsztyn, s. 67-85.

Kowalski J. (2000), Chronologia grupy elblaskiej i olsztyńskiej kręgu zachodnio-battyjskiego (V-VII w.), „Barbaricum”, t. 6, Warszawa, s. 203-248.

Kühn H. (1956), Das Problem der Masurgermanischen Fibeln in Ostpreussen, [w:] Documenta Archaeologica Wolfgang La Baume Dedicata, hrsg. O. Kleemann, Reinische Forschungen zur Vorgeschichte, Bd. 5, Verlag Röhrscheid, Bonn, S. 79-108.

Laux F. (1998), Fensterurnen-Lochgefäße, [w:] 100 Jahre Helms Museum. Verbogene Schätze in den Sammlungen, hrsg. R. Busch, Veröffentlichungen des HelmsMuseums, Wachholtz, Neumünster, s. 78.

Nowakiewicz T., Wróblewski W. (2003), Ceramika ,pruska” $i$,,słowiańska” we wczesnośredniowiecznej Galindii, [w:] Stowianie i ich sqsiedzi we wczesnym średniowieczu, red. M. Dulinicz, Wydawnictwo UMCS, Instytut Archeologii i Etnologii PAN, Lublin-Warszawa, s. 166-181.

Nowakowski W. (1989a), Studia nad ceramika zachodniobattyjska z okresu wędrówek ludów. Problem tzw. pucharków na pustych nóżkach, „Barbaricum”, t. 1, Warszawa, s. 101-147.

Nowakowski W. (1989b), Kultura wielbarska a zachodniobaltyjski krag kulturowy, [w:] Kultura wielbarska w młodszym okresie rzymskim, t. 2, red. J. Gurba, A. Kokowski, UMCS, Lublin, s. 143-159.

Nowakowski W. (1995), Od Galindai do Galinditae. Z badań nad pradziejami baltyjskiego ludu z Pojezierza Mazurskiego, „Barbaricum”, t. 4, Warszawa.

Nowakowski W. (1998a), Die Funde der römischen Kaiserzeit und der Völkerwanderungszeit in Masuren, Museum für Vor- und Frühgeschichte, Berlin. 
Nowakowski W. (1998b), Jaćwieskie cmentarzysko warstwowe (?) w miejscowości Burdyniszki na Suwalszczyźnie, [w:] Studia z dziejów cywilizacji. Studia ofiarowane profesorowi Jerzemu Gassowskiemu w pięćdziesiata rocznice pracy naukowej, red, A. Buko, Instytut Archeologii Uniwersytetu Warszawskiego, Warszawa, s. 119-123.

Nowakowski W. (2000a), Die Olsztyn-Gruppe (masurgermanische Kultur) in der Völkerwanderungszeit. Das Problem ihrer chronologischen und territorialen Grenzen, [w:] Die spätrömischen Kaiserzeit und die frühe Völkerwanderungszeit in Mittel- und Osteuropa, red. M. Mączyńska, T. Grabarczyk, Wydawnictwo Uniwersytetu Łódzkiego, Łódź, s. 168-180.

Nowakowski W. (2000b), Dzieje zainteresowań archeologicznych w Prusach przed 1945 rokiem, [w:] Antiquitates Prussiae. Studia z archeologii dawnych ziem pruskich, red. J. Kolendo, W. Nowakowski, Instytut Archeologii Uniwersytetu Warszawskiego, Warszawa, s. 9-22.

Nowakowski W. (2000c), Die Balten zwischen Weichsel und Memel zwischen 400 und 800 n. Chr. Ein Entwurf der Forschungsproblematik, „Archaeologia Baltica”, t. IV, s. 9-25.

Nowakowski W. (bearb. von) (2001), Masuren, Corpus der Römischen Funde im Europäischen Barbaricum. Polen., Bd. 1, Instytut Archeologii Uniwersytetu Warszawskiego, Warszawa.

Nowakowski W. (2004a), Schyłek grupy olsztyńskiej-próba nowego spojrzenia. „,Nowe” materiały z cmentarzyska $w$ Wólce Prusinowskiej w powiecie mragowskim, „Komunikaty Mazursko-Warmińskie”, nr 4(246), s. 407-417.

Nowakowski W. (2004b), Cmentarzysko z okresu wpływów rzymskich $i$ z okresu wędrówek ludów w Muntowie, pow. Mragowski, „Barbaricum”, t. 7, Warszawa, s. 191-247.

Nowakowski W. (2005), Grób 600 ze stanowiska I w Kosewie na pojezierzu Mazurskim, [w:] Europa Barbarica. Ćwierć wieku archeologii w Masłomęczu, red. P. Łuczkiewicz, M. Gładysz-Juścińska, M. Juściński, B. Niezabitowska, S. Sadowski, Monumenta Studia Gothica 4, Wydawnictwio UMCS, Lublin, s. 361-367.

Okulicz J. (1958), Cmentarzysko z okresu rzymskiego odkryte w miejscowości Bogaczewo na przysiółku Kula, pow. Giżycko, ,Rocznik Olsztyński”, t. I, s. 47-116.

Okulicz J. (1973), Pradzieje ziem pruskich od późnego paleolitu do VII w. n.e., Monografie Dziejów Społecznych i Politycznych Warmii i Mazur, nr 1, Ossolineum, Wrocław.

Okulicz J. (1988), Problem ceramiki typu praskiego w grupie olsztyńskiej kultury zachodniobattyjskiej (VI-VII w. n.e.), „Pomorania Antiqua”, t. XIII, s. 103-133.

Okulicz-Kozaryn Ł. (1983), Życie codzienne Prusów i Jaćwięgów w wiekach średnich (IX-XIII w.), PIW, Warszawa. 
Okulicz-Kozaryn Ł. (1997), Dzieje Prusów, FNP, Leopoldinum, Wrocław.

Reich Ch., Menghin W. (2008), Prussia Sammlung w Museum für Vor-und Früfgeschichte w Berlinie, [w:] Archeologiczne księgi inwentarzowe dawnego Prussia Museum. Die archäologischen Inventarbücher aus dem ehemaligen PrussiaMизеит. Археологические инвентарные книги бывщего музея „Пруссия”, red. A. Bitner-Wróblewska, Aestiorum Hereditas t. I, Archiwum Państwowe w Olsztynie, Olsztyn, s. 68-97.

Roeder F. (1928), Die sächsischen Fenstergefäße der Völkerwanderungszeit, „Bericht der Römisch Germanischen Komission”, t. 18, s. 149-187.

Rudnicki M. (2004), Grób grupy olsztyńskiej z miejscowości Piecki, woj. warmińsko-mazurskie, „Barbaricum”, t. 7, Warszawa, s. 265-273.

Rudnicki M. (2010a), Zabytki z kompleksu nekropoli w Kosewie, pow. mragowski jako przykład rozwoju i kontaktów grupy olsztyńskiej w późnym okresie wędrówek ludów, Warszawa. Niepublikowana rozprawa doktorska, Archiwum Instytutu Archeologii Uniwersytetu Warszawskiego.

Rudnicki M. (2010b), Grób 368 w Kosewie. Uwagi ponad 100 lat po odkryciu, [w:] Terra Barbarica. Studia ofiarowane Magdalenie Maczyńskiej w 65. rocznicęurodzin, red. R. Prochowicz, J. Schuster, A. Urbaniak, Monumenta Archaeologica Barbarica, Series Gemina, t. II, Instytut Archeologii Uniwersytetu Łódzkiego, Fundacja MAB, Łódź-Warszawa, s. 445-456.

Sabaciński M. (2002), Materiał osteologiczny z Szestna-Czarnego Lasu, stan. Jako źródło informacji o pruskim stosie pogrzebowym, „Światowit”, t. IV (XLV), s. $205-228$.

Stawiarska T. (2003), Czarka z okresu wędrówek ludów z Mazur, [w:] Słowianie $i$ ich sqsiedzi we wczesnym średniowieczu, red. M. Dulinicz, Wydawnictwo UMCS, Instytut Archeologii i Etnologii PAN, Lublin-Warszawa, s. 155-163.

Szter I. (2010), Cmentarzysko z okresu wplywów rzymakich i okresu wędrówek ludów w Kamieniu na Pojezierzu Mazurskim, „Wiadomości Archeologiczne”, t. LXI, s. 200-332.

Szymański P. (2004), Cmentarzysko kultury bogaczewskiej i grupy olsztyńskiej w Zalcu koło Mragowa, na Pojezierzu Mazurskim, „Barbaricum”, t. 7, Warszawa, s. $153-190$.

Szymański P. (2005), Mikroregion osadniczy z okresu wplywów rzymskich $w$ rejonie jeziora Salęt na Pojezierzu Mazurskim, „Światowit”, Suplement Series P: Prehistory and Middle Ages, vol. 10, Warszawa.

Urbańczyk P. (1978), Geneza wczesnośredniowiecznych metalowych pochew broni biatej ze stanowisk kultury pruskiej, „Przegląd Archeologiczny”, t. 26, s. $107-145$.

Valujev A. (1995), Die Geschichte des Kliningrader Bestandes der Prussia-Sammlung, [w:] Die Prussia Sammlung. Der Bestand im Museum für Geschichte und 
Kunst Kaliningrad, hrsg. Ph. Adlung, C. V. Carnap-Bornheim, T. Ibsen, A. Valujev, Hauschil, Schleswig, s. 49-111.

Valujev A. (2008), Historia odkrycia ksiag inwentarzowych i części zbiorów PrussiaMuseum w Kaliningradzie, [w:] Archeologiczne księgi inwentarzowe dawnego Prussia Museum. Die archäologischen Inventarbücher aus dem ehemaligen Prussia-Museum. Археологические инвентарные книги бывшего музея „Пруссия”, red. A. Bitner-Wróblewska, Aestiorum Hereditas, t. I, Archiwum Państwowe w Olsztynie, Olsztyn, s. 98-109.

Voigttmann K. (1941), Die westmasurische „Loch- und Fensterurnen, „Alt-Preußen”, t. 6, s. 36-46.

Weller K. (1937), Der Ursprung der säschsischen Fenstergefäße der Völkerwanderungszeit, „Mannus”, t. 29, s. 187-192.

Wiśniewska A. (2014), Łężany. Cmentarzysko z okresu wpływów rzymskich $i$ wędrówek ludów na Pojezierzu Mragowskim. Badania w sezonie 2013, Fundacja Dajna im. Jerzego Okulicza-Kozaryna, Warszawa.

Wróblewski W. (2000), Ossa cremata. Obrzadek pogrzebowy Galindów we wczesnym średniowieczu w świetle znalezisk na grodzisku w Szestnie-Czarnym Lesie, „Światowit”, t. 43, Fasc. B, s. 268-285.

Wróblewski W. (2006a), Aschenplätze - the forgotten burial rituals of the old Prussians, „Archaeologia Lituana”, t. 7, s. 221-234.

Wróblewski W. (2006b), Ziemie pruskie i jaćwieskie w okresie plemiennym (VII/VIIIXII/XIII wieku), [w:] Stan i potrzeby badań nad wczesnym średniowieczem w Polsce, 15 lat później, red. W. Chudziak, S. Moździoch, Instytut Archeologii UMK, Instytut Archeologii i Etnologii PAN, Toruń-Wrocław, s. 285-309.

Wróblewski W. (2007), „Wędrujace” pogranicze. Poludniowa rubież osadnictwa pruskiego w okresie plemiennym (VII/VIII-XII/XIII w.), [w:] Pogranicze polsko-pruskie i krzyżackie, t. II, red. K. Grążawski, Włocławskie Towarzystwo Naukowe, Muzeum w Brodnicy, Włocławek-Brodnica, s. 39-58.

Wróblewski W., Nowakiewicz W., Bogucki M. (2003), Terra desolata. Wczesnośredniowieczna Galindia $w$ świetle badań mikroregionu Jeziora Salęt, Studia Galindzkie, t. 1, Instytut Archeologii Uniwersytetu Warszawskiego, Warszawa, s. 157-180. 
Summary

\section{REMARKS ON THE BURIAL RITES OF THE OLSZTYN GROUP FOR EXAMPLE CEMETERY AT KOSEWO (FORMER KOSSEWEN, KR. SENSBURG)}

The cemetery in Kosewo (former Kossewen, Kr. Sensburg; from 1938, Rechenberg) is one of the largest known necropolises dated to the Roman and Migration Periods found in the Mazurian Lakeland. The site was accidentally discovered during the construction works of the road linking Mragowo with Mikołajki in 1887. Even though a large number of features was discovered at the cemetery in Kosewo, only single finds or assemblages from that site have been published.

At the cemetery in Kosewo there were pit and urn burials. The pit burials contained, besides the remains of the deceased, also the remains of the pyre. The predominant burial type were urn graves. Among the 728 recorded burials the majority were urn graves, amounting to 611. It seems justifiable to assume that in the Olsztyn group the urn graves were generally predominant, with some local departures from the custom. We may also say that the graves from the late Migration Period were deposited closer to the surface than the ones from the Roman Period. This phenomenon has been also recorded at the other cemeteries of the Olsztyn Group.

In the eastern part of the area settled by the Olsztyn Group, in which the Kosewo cemeteries are located, the burial grounds were usually made in the same places as the necropolises of the Bogaczewo culture. Large cemeteries used only in the Late Migration Period are exceptional. Graves from Phase E usually did not disturb the earlier burials, but at the cemetery in Kosewo this happened quite often. Basing on the research conducted so far it is possible to state that the graves from the Olsztyn Group were usually located in separate clusters located away from the graves from the Roman Period or only slightly overlapping with them.

In the urn graves of the Olsztyn Group the urns are sometimes covered with overturned bowl- or plate-shaped vessels, or beakers with hollow stems. No stone linings, pavements, or cist graves have been registered. Also no horse graves, which can be found in Mazuria of the Roman and Migration Periods, have been discovered at the cemetery in Kosewo. The cemetery yielded some finds of weapons in the assemblages dated to Phase E.

The decline of the Olsztyn Group is connected with the disappearance of archaeologically recordable burial rites. The change of the form of the burial rite probably did not concern cremation, which is recorded for the Prussian tribes from the Early Middle Ages. The change of the burial rites probably consisted in the introduction of a different form of deposition of the burials. Also at the cemetery in Kosewo no materials later than the 7th century have been recorded. The necropolis may have been abandoned or the way of depositing the burials was changed. The question about the final stages of use of the Olsztyn Group cemeteries may be answered by further investigations. 


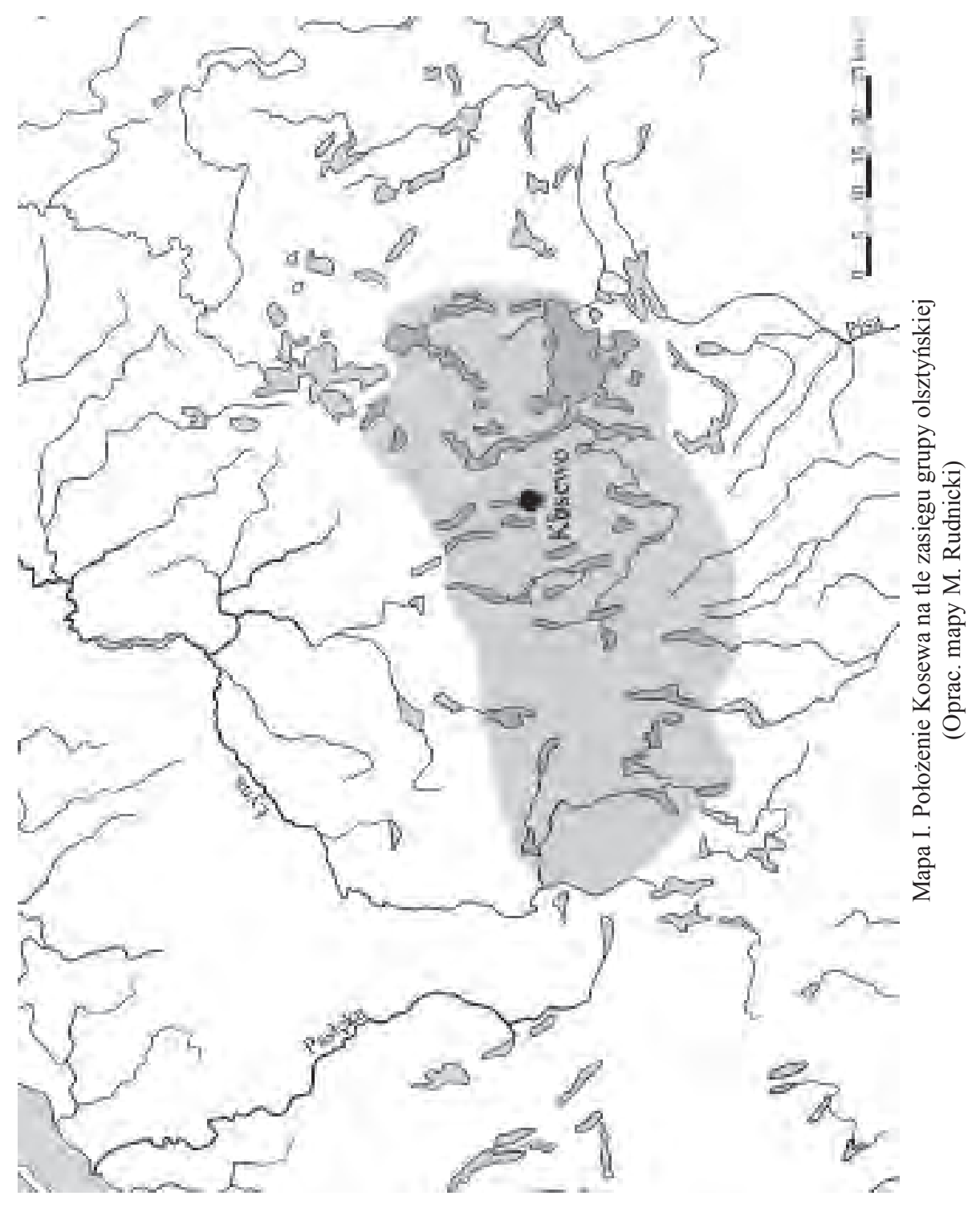




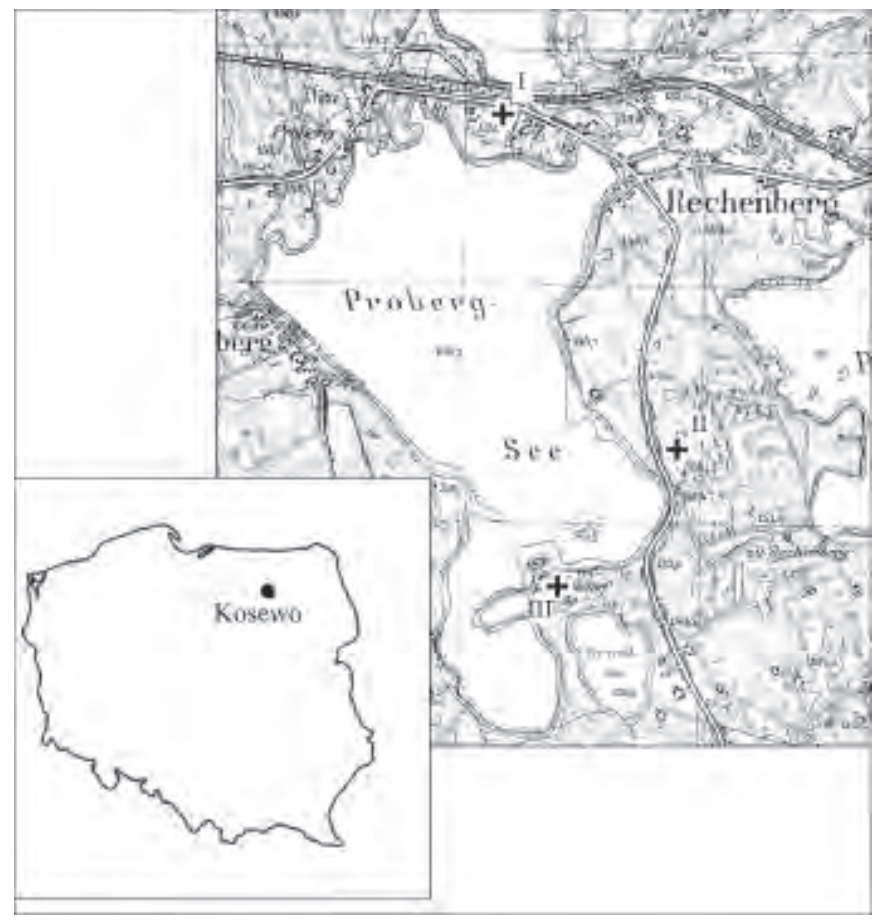

Ryc. 1. Położenie cmentarzyska w Kosewie (Źródło: Hilberg 2009)

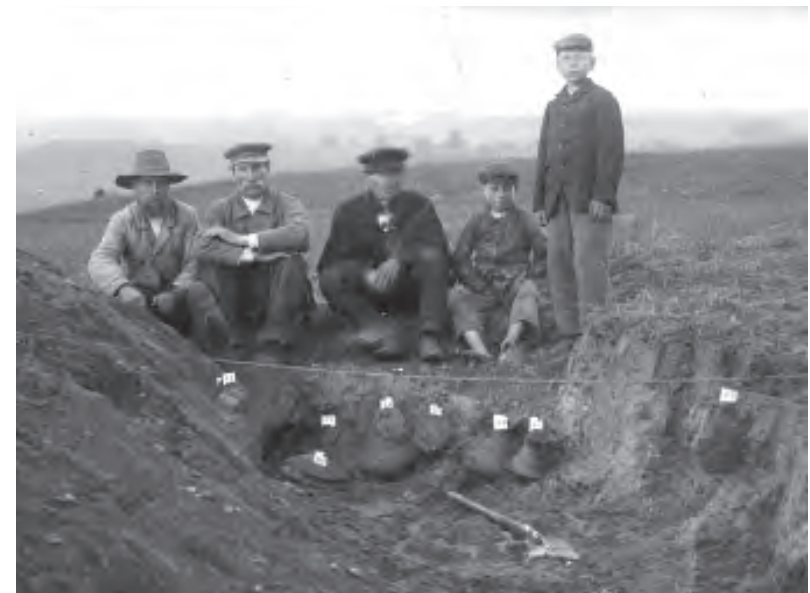

Ryc. 2. Fotografia przedstawiająca robotników zaangażowanych $\mathrm{w}$ prace wykopaliskowe na cmentarzysku Kosewo I w maju $1908 \mathrm{r}$.

(Źródło: P-M A 1848/4, fot. prawdopodb. 17.05.1908 r.) 


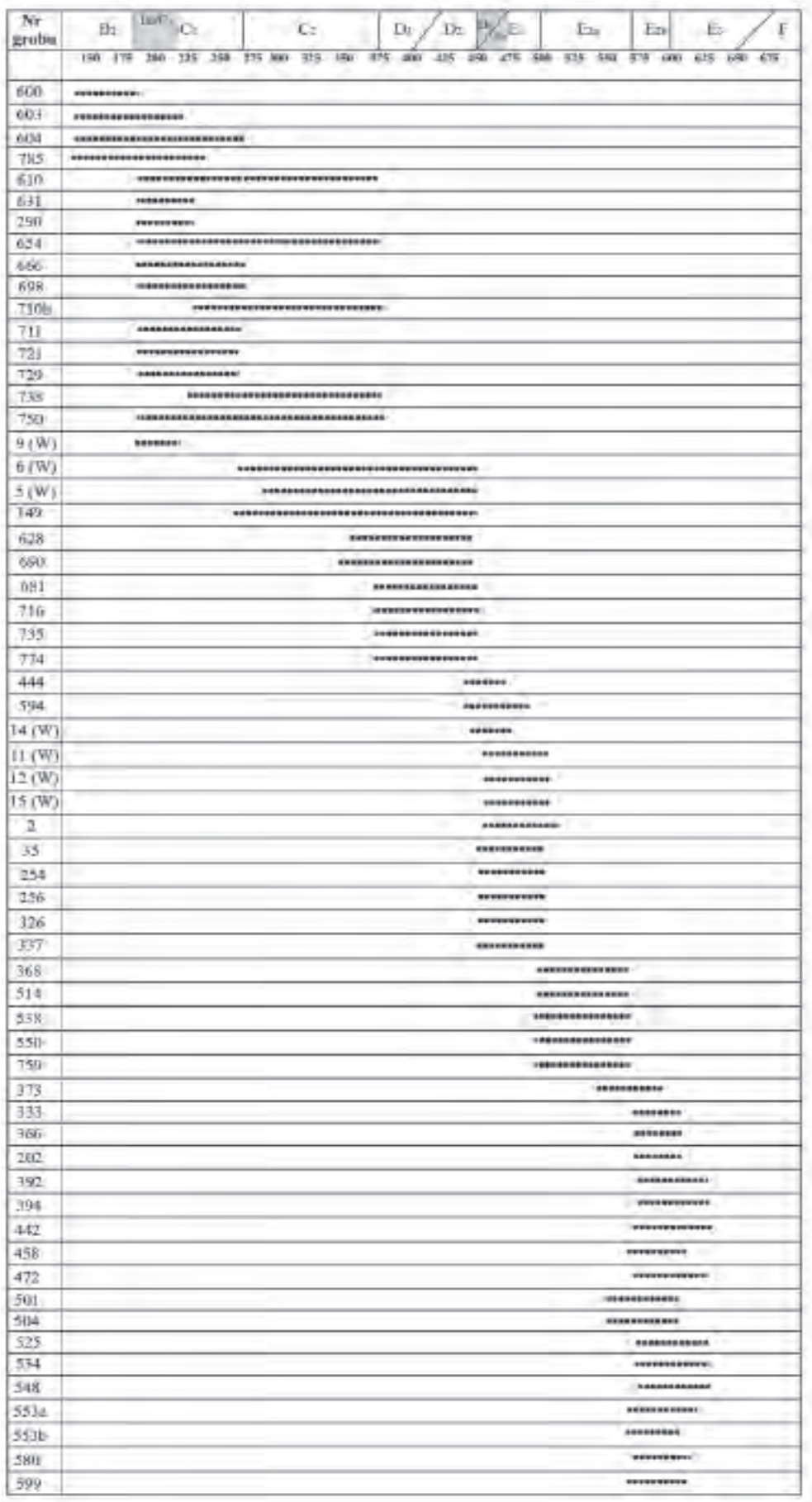

Ryc. 3. Rozpiętość chronologiczna cmentarzyska Kosewo I (Źródło: Rudnicki 2010a) 